\title{
Recikliranje antičkih epigrafskih spomenika na širem splitskom području
}

Dino Demicheli

DOI: $10.17234 / 9789531757232-12$

Uvod

Ono po čemu je Salona specifična jest to da usprkos činjenicama da su njezine ruševine stoljećima služile kao kamenolom i da je još i dalje većim dijelom neistražena, ima epigrafsku baštinu koja ide u red najbogatijih u Rimskome Carstvu. Dosad je u Saloni i njezinoj najbližoj okolici pronađeno više od 6000 epigrafskih spomenika. Kao i posvuda drugdje na teritoriju Rimskoga Carstva, većina natpisa je funerarnog karaktera. Želja za trajnim spomenom čovjekove prisutnosti u vremenu i prostoru može se primijetiti i u potrebi za kamenim nadgrobnim spomenikom. Nadgrobni su spomenici s natpisom uglavnom bili izloženi na nekropolama koje su se razvijale uz glavne cestovne komunikacije izvan gradskih bedema i na taj bi način bili dostupni pogledu prolaznika koji su pritjecali u grad ili odlazili izvan njega. Ondašnje je stanovništvo bilo itekako svjesno da u kamenu uklesani trag o pojedincu ima mnogo veći doseg u kolektivnom društvenom sjećanju nego trag na nekom manje trajnom materijalu. Naposljetku, stotine tisuća raznih individua poznate su isključivo jer su svoja imena uklesale u kamen. Opća pismenost stanovništva na nekom prostoru i dostupnost kamene građe rezultira i puno bolje zastupljenim pisanim spomenicima o njemu samome. To se najbolje očituje u činjenici da danas poznajemo više imena Salonitanaca nego stanovnika na čitavom ovom području u idućih više od tisuću godina nakon završetka antike.

Prema podatcima dobivenim iz arheoloških istraživanja na salonitanskom području većina je epigrafskih spomenika pronađena izvan njihova originalnog okruženja. Najviše je natpisa otkriveno u razdoblju od sredine 19. stoljeća do Drugoga svjetskog rata, od čega velika većina za vrijeme istraživanja don Frane Bulića. Iz njegovih se objava može vidjeti da su spomenici bili nalaženi na raznim mjestima: u kamenim gomilama maslinika i vinograda u Solinu; kao građevinski materijal recikliran već u antičkim i kasnoantičkim objektima; kao ponovno upotrijebljeni nadgrobni spomenici; kao materijal od kojeg su građeni dijelovi stambene arhitekture; kao materijal korišten za gradnju i dekoraciju crkava i sl. Tek je dio epigrafskih spomenika pronađen u svom izvornom ambijentu, a to se ponajviše odnosi na ranokršćanske natpise na sarkofazima pronađene na salonitanskim ranokršćanskim grobnim kompleksima, posebice na Manastirinama. 
Raznošenje antičkih epigrafskih spomenika i njihova ponovna upotreba u posve drugoj namjeni specifičnost je čitavog područja na kojem su grčka i rimska civilizacija ostavile svoj trag. Tragovi takve prakse mogu se pratiti već od same antike, kada se ponekad kao građevinski materijal za zidove javnih objekata ili za bedeme koriste epigrafski spomenici. Ipak, recikliranje spomenika u antici javlja se sporadično i relativno rijetko, no kasna je antika po tom pitanju bila iznimno aktivno razdoblje, pogotovo u periodima obnove građevina uslijed ratnih razaranja. I u samome gradu Rimu iskorištavanje kamenih spomenika u drugu svrhu najbolje je vidljivo od Konstantinova razdoblja nadalje, kada su stupovi, kapiteli i arhitravi ranijih građevina interpolirani u nove strukture (Brenk 1987: 103). Upravo monumentalni Konstantinov slavoluk u Rimu to jako zorno prikazuje, jer je i sam u određenoj mjeri sastavljen od spolija sa spomenika koji su nekoć veličali uspjehe prijašnjih careva (Trajana, Hadrijana i Marka Aurelija). Tako su čak i prikazi samog Konstantina bili napravljeni od remodeliranih portreta Trajana i Hadrijana (Elsner 2000: 159-162).

Ne možemo znati kakav je bio generalni stav stanovništva prema sekundarnoj upotrebi dijelova arhitektonske plastike, no vrlo se znakovitim čini rečenica iz "Novele o javnim građevinama" (De aedificiis publicis) rimskog cara Majorijana iz 458. god. koji se osvrnuo na razgrađivanje zgrada u Rimu koje je dotad trajalo već stoljeće i pol: Dok se pretvaraju da je potrebna kamena građa za javne radove, prekrasne strukture starih građevina se rastavljaju i velebne se stvari ruše kako bi nešto beznačajno bilo popravljeno. ${ }^{1}$

Sama riječ spolia, -orum u latinskom jeziku označuje oderanu životinjsku kožu, a potom i ratni plijen, no pod stručnim terminom spolia, koji je nastao početkom 16. stoljeća, misli se na dijelove nekadašnjih zanatski ili umjetnički obrađenih (najčešće kamenih) spomenika građevina, skulpture, nadgrobnih spomenika, dekorativne plastike i sl. koji su „oteti“ svom prvobitnom okruženju i najčešće u preinačenom obliku (preklesanom, otpiljenom, fragmentiranom) iskorišteni pri gradnji novih arhitektonskih sklopova ili izradi novih predmeta. Ovisno o tipu buduće namjene, iskorištavale su se različite vrste kamenih spomenika, a u graditeljstvu često dolaze u kombinaciji npr. arhitektonska plastika i natpisi, a ponekad i s dijelovima skulpture. U širem smislu riječi spoliji predstavljaju dokaze o uništenju, odnosno oni su ostatci nekog nasilnog procesa koji je uzrokovao čovjek, priroda ili vrijeme (Kinney 1995: 59), ali isto tako spoliji su važno svjedočanstvo o promjenama koje su doživjele određene građevine i kako se neki grad razvijao (Piplović 2005: 10).

Otkad se ovaj fenomen počeo proučavati, na njega se uglavnom gledalo negativno. Tijekom 20 . stoljeća gledište se počelo mijenjati te je današnji stav uvelike drukčiji: ono što je nekoć bila damnatio memoriae, u današnjim se interpretacijama češće sagledava kao renovatio memoriae (Kinney 1997). Danas se umjetnost i graditeljstvo kasne antike uopće ne mogu promatrati ne imajući na umu koliko je tijekom tog razdoblja antički materijal bio recikliran. Interes za proučavanjem spolija posebno je živ posljednja četiri desetljeća. Uglavnom prevladavaju kritički osvrti i ocjene na skulpturu i arhitekturu u sekundarnoj uporabi i to uglavnom sa stajališta povijesti umjetnosti, dok su interpretacije natpisa kao spolija zastupljene u nešto manjoj mjeri. ${ }^{2}$

O spolijima najčešće razmišljamo kao o materijalu koji je ponovno iskorišten za gradnju ili prenamjenu u neki drugi utilitarni komad. 0 nečijim razlozima ponovnog korištenja nekog kamenog spomenika u posve novu svrhu može se nadugo raspravljati, no česta polazišna točka je ekonomičnost, odnosno praktičnost. Tijekom povijesti mnogi su se posjedi nalazili na područjima nekadašnjih urbanih aglomeracija te je obrađena kamena građa bila dostupna mnogim naseljenicima nekog prostora. Gledajući područje nekadašnjeg salonitanskoga agera, na osnovi

\footnotetext{
${ }^{1}$ NMaj. 4.1, Dum necessaria publico operi saxa finguntur, antiquarum aedium dissipatur speciosa constructio et ut parvum aliquid reparetur, magna diruuntur.

2 Literatura o spolijima, posebno u gradu Rimu, iznimno je velika. Navest ću samo neka bitna djela i ona koja sadržavaju šire popise literature: Brenk 1987; Alchermes 1994; Kajanto 1995; Kinney 1995; 1997; 2006; Cooley 2000; Elsner 2000; CoatesStephens 2002; Altekamp et al. 2013.
} 
dosad potvrđenih arheoloških ostataka, može se zaključiti da je ovaj prostor bio poprilično napučen, ali i izgrađen. Kvalitetne kamene građe za gradnju uistinu nije nedostajalo: još uvijek aktivni kamenolomi na Braču kao i u Segetu kod Trogira u antici su bili primarni izvori sirovine za ovo čitavo područje.

Spoliji nisu posebnost jednog određenog razdoblja, oni su univerzalni odgovor na tehnološka i materijalna ograničenja (Kinney 2006: 233). Ipak, kada govorimo o ponovnoj uporabi kamenih spomenika, ovaj običaj i razlog njihova iskorištavanja ponekad nadilazi potrebu graditelja za ekonomskom isplativošću ili praktičnošću, s obzirom na to da se radi o već obrađenim (i često besplatnim) komadima koji se mogu upotrijebiti pri gradnji. Segment ekonomske isplativosti je svakako važan faktor, no, ovisno o razdoblju u kojima je neki komad ponovno iskorišten, mogu se uzeti u obzir i drukčiji porivi kojima su se povodili graditelji. Sagledavajući ponovnu uporabu spomeničke građe u cjelini, može se govoriti o višesložnom sociološkom fenomenu. Osim spomenutih praktičnih razloga, tu se može govoriti o estetsko-dekorativnim; ugradbom spomenika u privatnu kuću vlasnik može slati određenu poruku društvu koja ga prikazuje u svjetlu ljubitelja baštine; s druge strane, ugradnjom kamenih fragmenata s poganskim obilježjima može se naglasiti simbolika pobjede kršćanstva nad poganskim politeizmom itd. Postoji, dakle, mnogo mogućih razloga recikliranja nekog spomenika o kojima danas, s vremenske distance, možemo samo govoriti u teoriji, no svakako se može reći da je ova praksa uvelike odraz društvenih zbivanja na područjima u kojima se javlja.

U tekstu koji slijedi bit će manje riječi o mogućim razlozima, a više o konkretnim primjerima kroz koje se može u osnovnim crtama sagledati razmjer ove kulturološki zanimljive prakse. Epigrafski su spoliji u provinciji Dalmaciji dobro posvjedočeni na mnogim lokalitetima, a kao posebne izdvojit ću bedeme Aserije (Podgrađe kod Benkovca) kao dobar primjer iskorištavanja nadgrobnih natpisa u kasnoj antici ${ }^{3}$ i Erešovu kulu u Vidu (Narona), kao izvrstan primjer obilate ugradbe većinom epigrafskih spolija u novovjekovnu zgradu (19. st.). ${ }^{4} 0$ antičkim spolijima općenito pisali su mnogi, no ovdje ću samo spomenuti tri novija rada koja su obrađivala ovaj fenomen u Dalmaciji. Rad Ive Babića donosi općeniti pregled antičkih spolija u ranosrednjovjekovnoj Hrvatskoj (Babić 2006); rad Stanka Piplovića bavi se recikliranjem arhitektonskih i skulpturnih elemenata u Saloni (Piplović 2005); M. Barišić i V. Marinković pisali su o fenomenu antičkih spolija i o problemu njihove zaštite i prezentacije na području Splita i Kaštela (Barišić \& Marinković 2011).

U ovom ću se radu ograničiti i predmetno i geografski: bit će opisani primjeri reciklaže antičkih epigrafskih spomenika, uz tek pokoji primjer drugih vrsta spomenika, jer bi i samo sumaran prikaz svih vrsta spolija na ovome području bio preopširan; geografski je rad usmjeren na današnje šire splitsko područje koje je nekoć većim dijelom obuhvaćao salonitanski ager. Kronoloških ograničenja u radu nema, budući da su pokriveni primjeri iz svih perioda u kojima su korišteni antički natpisi u nove svrhe.

\section{Epigrafski spoliji kao građevinski materijal}

Najčešća i najrasprostranjenija primjena reciklaže antičke natpisne građe je upotreba natpisa kao građevinskog materijala. Tijekom svih povijesnih razdoblja na širem splitskom području antički i kasnoantički natpisi obilato su se koristili u gradnji objekata svih namjena, pogotovo stele, nadgrobne are i počasne baze s obzirom na to da se radi o već gotovim, uglavnom pravilno obrađenim komadima kamena. Ova praksa nije karakteristika samo jednog razdoblja već se

\footnotetext{
${ }^{3}$ Natpise je najvećim dijelom objavio I. Fadić na stranicama časopisa Asseria.

${ }^{4}$ Natpisi su, osim u CIL-u, publicirani u zasebnoj monografiji (Marin et al. 1999). Ugrađeno je više od 40 natpisa, od kojih je većina original, dok se kod nekolicine radi o novoizrađenim rustičnim kopijama natpisa pronađenim na drugim lokalitetima.
} 


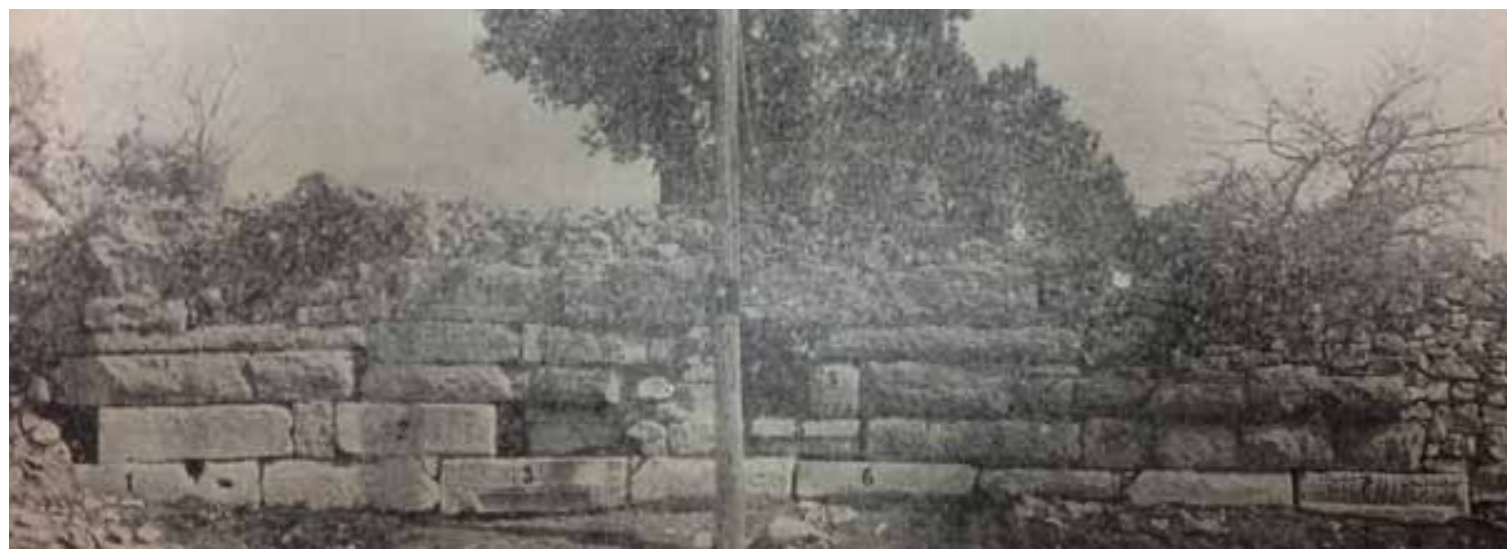

ona može konstantno pratiti od antike do 20. stoljeća (s iznimnim primjerima i u 21. st.). Gotovo da nema vrste građevine u koji spoliji nisu bili korišteni, od stambenih objekata do krčmi i pojata, od mlinica i konoba do bedema, od popločenja ulica do gradnje crkava i zvonika. Ovdje ću spomenuti podatak da se salonitansko kamenje tijekom povijesti uvelike raznosilo, ne samo lokalno, na području oko Salone, nego, nažalost, i na suprotnu jadransku obalu. Poznato je da su Mlečani odnosili silne količine drvne i kamene građe s naših obala te da je pritom posebno stradala Salona, koja je stoljećima služila kao kamenolom za gradnju venecijanskih crkava i palača (Fisković 1952). Nema sumnje da su među ovom građom odneseni i mnogi natpisi iz Salone te je moguće da se među spolijima koji su uzidani u venecijanske građevine nalaze i komadi iz Dalmacije. ${ }^{5}$ Takve su pretpostavke teško dokazive, no dobro je da se u svim budućim raspravama o natpisima s venecijanskog prostora uvrsti mogućnost da su podrijetlom s naših obala. Spominjući odnesene natpise, treba dodati i da su brojni dalmatinski natpisi, među kojima ima i salonitanskih, bili dijelovi venecijanskih antikvarskih kolekcija, posebice one u Muzeju Nani (Calvelli et al. 2017). ${ }^{6}$

\section{Epigrafski spomenici u salonitanskim bedemima}

U istraživanjima salonitanskih bedema u posljednja dva stoljeća pronađena je veća količina natpisa koji su ondje završili kao građevinski materijal u raznim periodima, jer su tijekom stoljeća bedemi zahtijevali obnovu, pogotovo u 6. st. Natpisi koji se mogu sagledati kao spoliji pronađeni su i u samim bedemima i u urušenim dijelovima bedema, a radi se najčešće o nadgrobnim arama i stelama (Bulić 1902; 1903; 1910; 1914a; Abramić 1932). ${ }^{7}$ Salonitanski su bedemi građeni 170. god. zbog opasnosti od provale Markomana, Kvada i Jaziga, a radilo se o poduhvatu koji je trebao biti brzo izveden. Veličina grada Salone tada je već uvelike nadrasla prostor koji je dvjestotinjak godina prije bio ograđen prvim gradskim zidinama i koji je bio dovoljan potrebama stanovništva u Augustovo doba. Novi su bedemi morali obuhvatiti i zaštititi gradska proširenja, prije svega na istok i na zapad, što je i učinjeno njihovom izgradnjom u duljini od nešto više od 4 kilometra. Sigurno je da je tijekom urbanističkog planiranja postojanje nekoliko gradskih nekropola predstavljalo određeni problem. Naime, kako se prema rimskome

\footnotetext{
${ }^{5}$ Na to u novije vrijeme ukazuje talijanski epigrafičar L. Calvelli (2015).

${ }^{6}$ Raznošenjem zbirke nekadašnjeg Muzeja Nani nekim se spomenicima gubi trag, dok ih je nešto više od 20 iz Dalmacije izloženo u lapidariju muzeja u gradiću Piazzola sul Brenta koji se nalazi pored Padove.

${ }^{7}$ Navest ću neke od najznačajnijih natpisa iz bedema: CIL III 1988, 1997, 2075, 8713, 8740, 8745, 8764, 8806, 8967, 9301, 9302, 9379, 9450, 14712, 14713, 147771, 148272; ILJug 2074, 2076, 2203.
} 
zakonu nitko nije smio pokapati unutar gradskih zidova, nekropole su se uvijek gradile izvan njih. U drugom su se stoljeću tako dijelovi prvih salonitanskih nekropola već nalazili na prostoru koji će biti obuhvaćen bedemima, što je značio i prestanak funkcioniranja ovih grobišnih areala i njihovu djelomičnu anihilaciju.

Vjerojatno su oni spomenici koji su se prethodno nalazili na trasi bedema i dio spomenika koji su ostali unutar grada ugrađeni u nove gradske zidine. To se najbolje može vidjeti na potezu zapadnih bedema koji su presjekli najstarije salonitansko groblje, tzv. zapadnu nekropolu. Nemali je broj što čitavih spomenika što ulomaka izvađen iz zapadnoga dijela bedema, a najpoznatiji među njima je monumentalna nadgrobna ara Pomponije Vere. Radi se o najvećem, dosad, pronađenom nadgrobnom natpisu u Saloni, koji je zajedno s postoljem i kruništem bio fragmentiran u 11 komada (sl. $1 \mathrm{a}$ i $1 \mathrm{~b}$ ). Istom je prilikom na ovome mjestu pronađeno još 11 drugih epigrafskih spomenika (Bulić 1903; Piplović 2005: 2-3), dok je jedna manja kula na jugozapadnome dijelu bedema gotovo čitava bila izgrađena od spolija, među kojima je bilo i 17 natpisa (Glavinić 1881; Bulić 1903: 4; Abramić 1950: 15). Spomenut ću još dva vrlo značajna spomenika koja su nekoć bila na zapadnoj nekropoli, poznata portretna stela Gaja Utija $(C \text {. Utius })^{8}$ (1. st. pr. Kr.), pronađena kao nadvratnik malih vrata između dviju kula bedema i počasna ara Lucija Anicija Petinata ( $L$. Anicius Paetinas), jednog od najvažnijih salonitanskih gradskih i vjerskih dužnosnika u vrijeme namjesnika Publija Kornelija Dolabele (14.-20. god.). ${ }^{9}$

Na vidljivome dijelu istočnoga dijela bedema, osim građevinskih natpisa koji su ondje izvorno bili postavljeni ${ }^{10}$, i danas stoje epigrafski spoliji koji nisu izvađeni iz njih (sl. 2). Prilikom svakih novih arheoloških istraživanja bedema pronađe se poneki spomenik. U novije je vrijeme, pronađena i izvađena velika nadgrobna ara Tita Flavija Lucilija (T. Flavius Lucillius), vojnika s iznimno zanimljivom vojnom karijerom iz vremena cara Hadrijana (Jeličić-Radonić 2006a), a istom je prilikom izvađena još jedna nadgrobna ara sličnih dimenzija iz 1 . st. ${ }^{11}$ Da nisu samo veći spomenici završavali u bedemima, svjedoče i pronalasci manjih stela i prepolovljenih manjih ara koje su ondje pronalažene (v. npr. Jeličić-Radonić 1998: 30-32). Više epigrafskih spomenika, uglavnom stela, pronađeno je prilikom zaštitnih radova na istočnom traktu bedema u Zvonimirovoj ulici u Solinu, a u kuli, u kojoj su spomenici bili uzidani, nalazio se i zavjetni natpis posvećen bogu Prijapu (Mardešić 2000: 148). Primjer iznimno lijepe velike portretne stele pruža spomenik Kvinta Metija Valenta koja je, zajedno s još jednom većom stelom pronađena 80-ih godina u blizini prve kule južno od porta Andetria na istočnom potezu salonitanskih bedema (Cambi 1986: 84-86).

Korištenje nečijeg nadgrobnog spomenika u tako banalnu svrhu kao što je obični građevinski materijal u potpunoj je suprotnosti s konceptom nepovredivosti posvećenog grobnog mjesta i nadgrobnog spomenika koji su res sacrae. Radi se o drugoj polovini 2. st. te je gotovo nevjerojatno da su za ovu gradnju korišteni spomenici od kojih su neki bili izrađeni tek koje desetljeće ranije. Ovakva je intervencija vjerojatno trebala biti pravno i vjerski regulirana, pogotovo stoga što se radilo o spomenicima na posvećenom tlu i za čije je održavanje sigurno bilo živućih potomaka ili nasljednika.

\footnotetext{
${ }^{8}$ ILJug 2203. O ovoj steli i pronalasku više u: Abramić 1932.

${ }^{9}$ CIL III 14712.

${ }^{10}$ CIL III 1979, 1980, 6374=8655. Postavljeni su tijekom gradnje ili obnove sa svrhom navođenja koja je vojna jedinica, kada i u kojoj dužini sagradila ili obnovila određeni dio bedema.

${ }^{11}$ Natpis je vjerojatno već u antici pretrpio temeljitu damnatio memoriae. Ara je neobjavljena.
} 


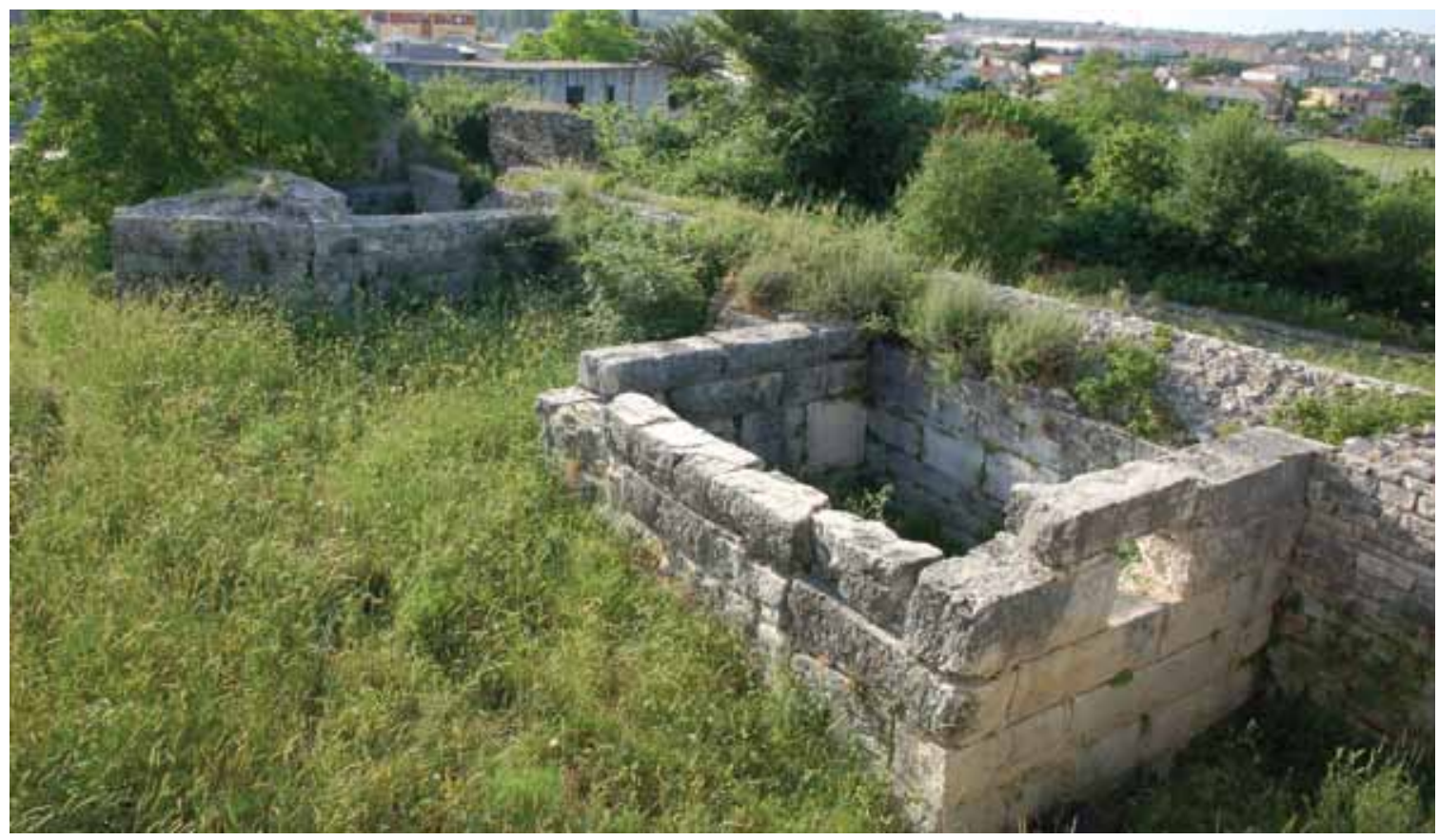

Pomalo ironično zvuči podatak da je i natpis o obnovi gradnje bedema iz prve polovine 5. stoljeća, koji je izvorno i bio ugrađen u reparirani dio bedema, završio kao popločenje hodne površine ispred bedema, po svoj prilici u 6. stoljeću (Jeličić-Radonić 2007: 18-19).

Kako je spomenuto, ugrađivanje nadgrobnih spomenika u druge građevine potpuno je zaživjelo u razdoblju kasne antike. Tada se svjetonazor na mnogim poljima promijenio, pa je praksa recikliranja nadgrobnih spomenika postala mnogo uobičajenija. Kako se već tada radilo o spomenicima odavno preminulih ljudi, može se pretpostaviti da su natpisi predstavljali tek dokaz njihova nekadašnjeg postojanja bez izravne veze s kršćanskim življem kasnoantičke Salone. Ovaj se stav posebno uočava pri korištenju antičkih sarkofaga u svrhu kršćanskog ukopa ili gradnje ranokršćanskih crkava, o čemu će biti kasnije riječi. U kršćanskom su razdoblju počasne baze nekadašnjim carevima, caricama te zaslužnim građanima, koje su nekoć stajale na gradskim trgovima u Saloni, sekundarno iskorištene pri gradnji ili reparaciji bedema, ali i drugih vrsta javnih građevina upravo u zamahu vjerske i svjetonazorske purifikacije javnih prostora. Kako su salonitanski bedemi tijekom niza idućih stoljeća služili kao kamenolom, nije na odmet ni pretpostavka da su počasni spomenici koji su pronađeni npr. u zvoniku splitske katedrale sv. Duje ustvari prethodno izvađeni iz ovih bedema (Demicheli \& Demicheli 2017).

\section{Epigrafski spomenici u svjetovnim građevinama antike i nakon nje}

U antičkim je građevinama koje su imale svoj kontinuitet sve do ranoga srednjeg vijeka, pa i kasnije, teško ustanoviti kada su spoliji dospjeli u njih. Može se pretpostaviti da su dijelovi salonitanskih nekropola koje su ostale unutar bedema, a time uskoro i prestale funkcionirati, postupno bili demontirani. Naime, nekadašnje nekropole izvan grada, nakon gradnje bedema 170. god. postale su grad mrtvih koji je egzistirao uz grad živih. Kako se gradsko tkivo i dalje razvijalo, nema sumnje da su dijelovi zapadne, istočne i jugoistočne nekropole malo pomalo 
SI. 3: Greda s natpisom ugrađena u nasip zajedno sa sarkofagom na istočnom dijelu Salone (fotografirao: D. Demicheli).

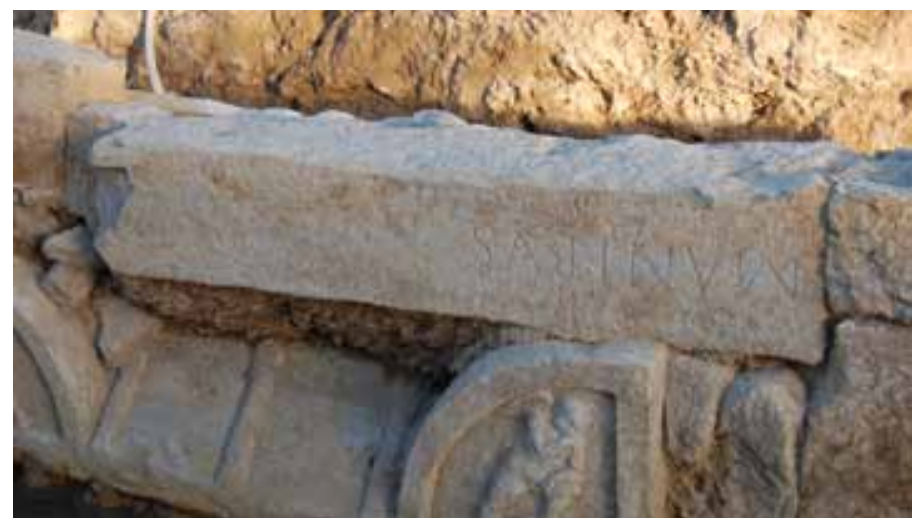

nestajali jer su predstavljali potencijalno vitalan gradski prostor. Nekropole izvan starijih gradskih bedema bile su razgrađene, što se vidi po vrlo slabim ostacima grobne arhitekture koja bi pripadala 1. st. pr. Kr. ili 1. st. kršćanske ere. Puno su bolje očuvane nekropole koje su bile izvan novoizgrađenih bedema. U gradu kao što je Salona, gdje je bilo na desetke tisuća epigrafskih spomenika, natpisi u svojoj sekundarnoj upotrebi uglavnom nisu prelazili veliku udaljenost u odnosu na prvobitnu poziciju. U tom kontekstu treba sagledati i početke uporabe nadgrobnih natpisa u građevinama koje slijede nekadašnje areale rasprostiranja nekropola (Miletić 1989; 1990; 1991). U blizini Porta Caesarea pronađen je poznati natpis (preskript) na grčkom jeziku iz 56. god. pr. Kr. koji spominje isejsko poslanstvo Cezaru. Natpis je imao probušen otvor po sredini te je služio kao poklopnica kanala odvodnih voda (Abramić 1925: 3-7). Nešto sjevernije od foruma u Saloni, kao popločenje ceste pronađen je ulomak natpisa sa spomenom Marka Pompeja Silvana (M. Pompeius Silvanus), provincijskog namjesnika iz treće četvrtine 1. st. Natpis je izvorno bio ugrađen u javno kupalište koje se spominje i povodom čije gradnje je natpis i bio izrađen (Rendić-Miočević 1985). Velike terme u Saloni nastale su u 2. stoljeću, a imaju nekoliko natpisa koji su bili u njih ugrađeni. ${ }^{12}$ Natpisi pripadaju kraju 2. ili počeku 3. stoljeća te je moguće da su ondje ugrađeni i prije kasne antike kada sama građevina doživljava određene preinake. U istraživanjima lokaliteta „Pet mostova“ istočno od Porta Caesarea otkriveni su natpisi u zidovima ovog kompleksa (Bulić 1914b), no ne zna se kada su onamo dospjeli, u kasnoj antici ili čak i ranije. Najpoznatiji natpis ugrađen kao spolij je počasna baza salonitanskog viteza i gradskog uglednika Marka Ulpija Sabina. ${ }^{13}$ Kao poklopnica vodovodnog kanala koji je išao po starim gradskim bedemima do Porta Caesarea bio je iskorišten donji dio vojničke stele, dok su za popravak akvedukta u blizini njegova izvora pronađene tri lijepe ploče s reljefnim prikazima Neptuna i morskih bića (Bulić 1914b: 73-75).

Jedan od najznačajnijih salonitanskih epigrafskih spomenika u posljednje vrijeme pronađenih je počasna baza za kip carice Aurelije Priske, supruge cara Dioklecijana, čiji je ovo ujedno i prvi epigrafski spomen u Carstvu. Spomenik je pronađen prepiljen na dva dijela, ugrađen u stranu odvodnog kasnoantičkog kanala u istočnome dijelu grada (Jeličić-Radonić 2009). Ovo se dogodilo u kasnoantičkome periodu pa je tim više zanimljiv podatak s obzirom na to, da je istočni dio Salone najviše prosperirao upravo u Dioklecijanovom razdoblju. Na istom je području, kao jedan od brojnih spolija u kanalu, bio ugrađen žrtvenik posvećen Jupiteru (JeličićRadonić 2006b: 46). Vjerojatno za potrebe reguliranja toka nekog od rukavaca rijeke Jadro u nekom je periodu kasne antike i podignut nasip sastavljen od velikih kamenih blokova i dijelova nadgrobne arhitekture. U ovaj su nasip ugrađeni prvoklasni mramorni sarkofazi, ulomci arhitektonske plastike, dijelovi stupova te jedna velika greda s ostatkom nadgrobnog natpisa (Nodilo 2008: 490-492, sl. 3). Pronađeni kameni materijal upućuje na to da je ovom prilikom razgrađen bogatiji dio istočne nekropole, moguće čak neki mauzolej.

12 ILJug 2149, 2177.

${ }^{13}$ ILJug 2109. 
SI. 4: Počasni natpis cara Proba (CIL III 8707) ugrađen u kuću u Bosanskoj ulici u Splitu (fotografirao: D. Demicheli).

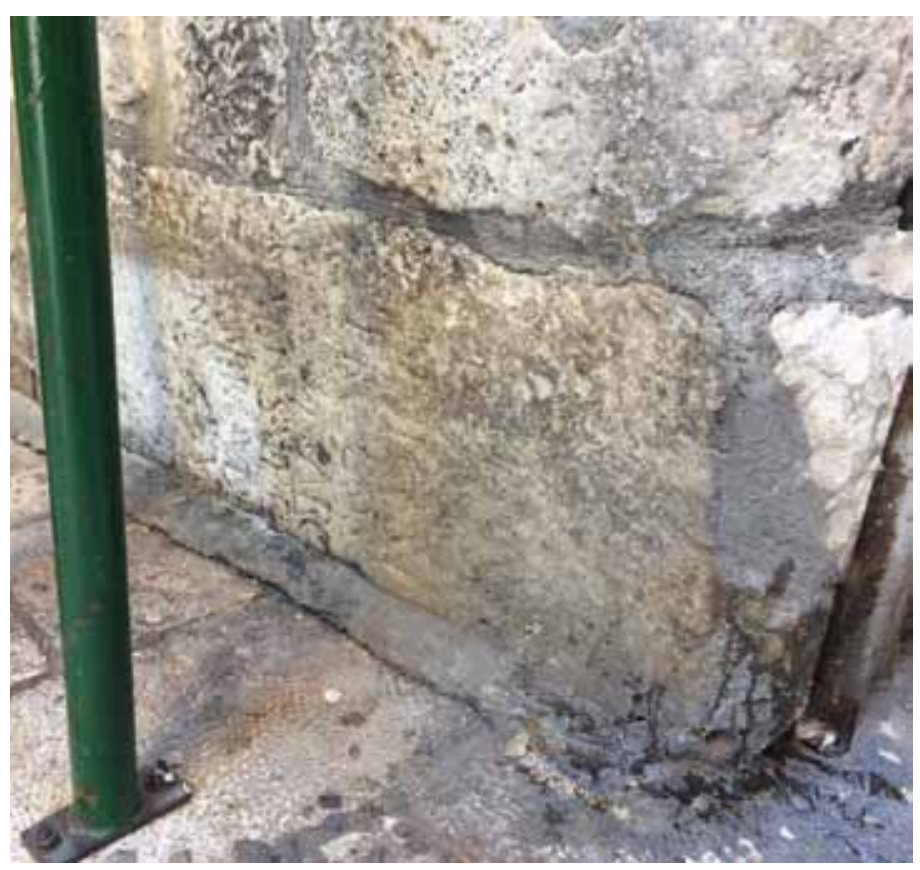

SI. 5: Antička stela s izmišljenim natpisom (CIL III 131*) iz doba humanizma (fotografirao: D. Demicheli).

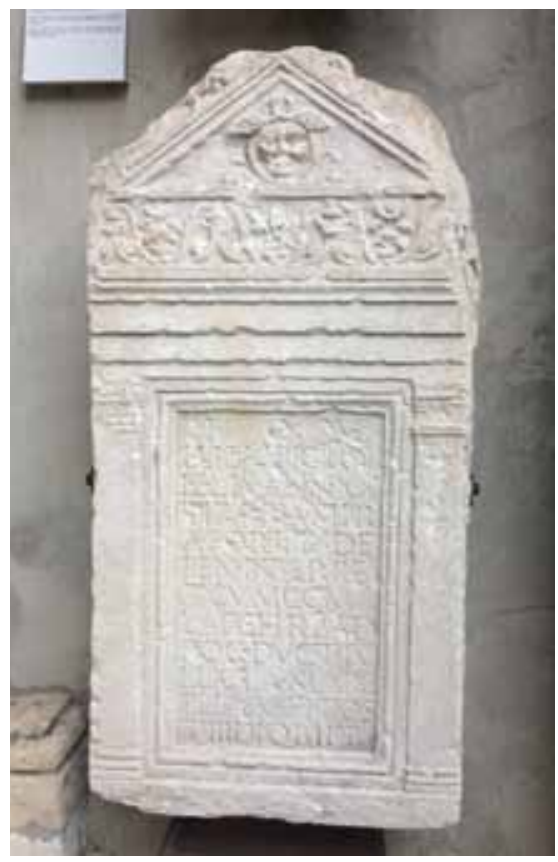

Najpoznatija građevina na ovim prostorima nastala u rimsko doba i koja je još uvijek u funkciji je Dioklecijanova palača. Ona je nastala u kasnoj antici i danas je spomenik koji pruža uvid u kontinuitet života od Dioklecijana do danas. Sama je palača bila izgrađena na već naseljenom području, što znači da je prethodno porušeno naselje koje se ondje nalazilo te je vrlo izgledno da su se za njezinu izgradnju barem u nekom segmentu koristili i dijelovi ranije arhitekture. Već pri samoj gradnji korišten je reciklirani materijal donesen čak iz Egipta (stupovi, sfinge, skulpture), što je na neki simboličan način odredilo i njezin daljnji razvoj. Naime, kako je Dioklecijanova palača prešla svoj put transformacije iz carskog posjeda u grad, doživjela je brojne preinake, rušenja i izgradnje koje su rezultirale konstantnom reciklažom kamenog materijala. Mnogi su prostori promijenili funkciju, počevši od Dioklecijanova mauzoleja koji je pretvoren u katedralu sv. Duje, pa do crkava koje su postale profane građevine, kao npr. crkvica sv. Roka na Peristilu. Danas je moguće vidjeti nemali broj uzidanih antičkih ulomaka u romaničkim, gotičkim, renesansnim i kasnijim građevinama. U širem smislu shvaćanja ove pojave, ovdje moram spomenuti i jedan od najranijih primjera reciklaže natpisa unutar Dioklecijanove palače, a radi se o hijeroglifskim natpisima na sfingama koje je Dioklecijan dao dopremiti iz Egipta i instalirati ih u svoju rezidenciju.

Unutar same Palače, ali i u njezinoj neposrednoj blizini, pronalaženi su brojni epigrafski spomenici koji su nastali prije njezine izgradnje. Ovi su natpisi u starijoj znanstvenoj literaturi uglavnom bili sagledani kao građa donesena iz Salone, što je sigurno samo za neke, no da tome nije uvijek tako, sada već svjedoči podosta arheoloških dokaza pronađenih na splitskom poluotoku koji život u rimsko doba ondje datiraju od 1. stoljeća. Navest ću samo dva primjera iz Palače: u supstrukcijama južnoga dijela Palače, u tzv. podrumima, tijekom stoljeća odlagala se razna kamena građa koja nije bila potrebna stanovništvu Splita. Kada se pristupilo njihovu čišćenju, pronađeno je i petnaestak natpisa, od kojih i dio epistilne grede s natpisom posvećenim $\mathrm{Au}-$ gustu i Tiberiju (Rendić-Miočević 1952: 170-175). Počasna baza s natpisom posvećenim caru 


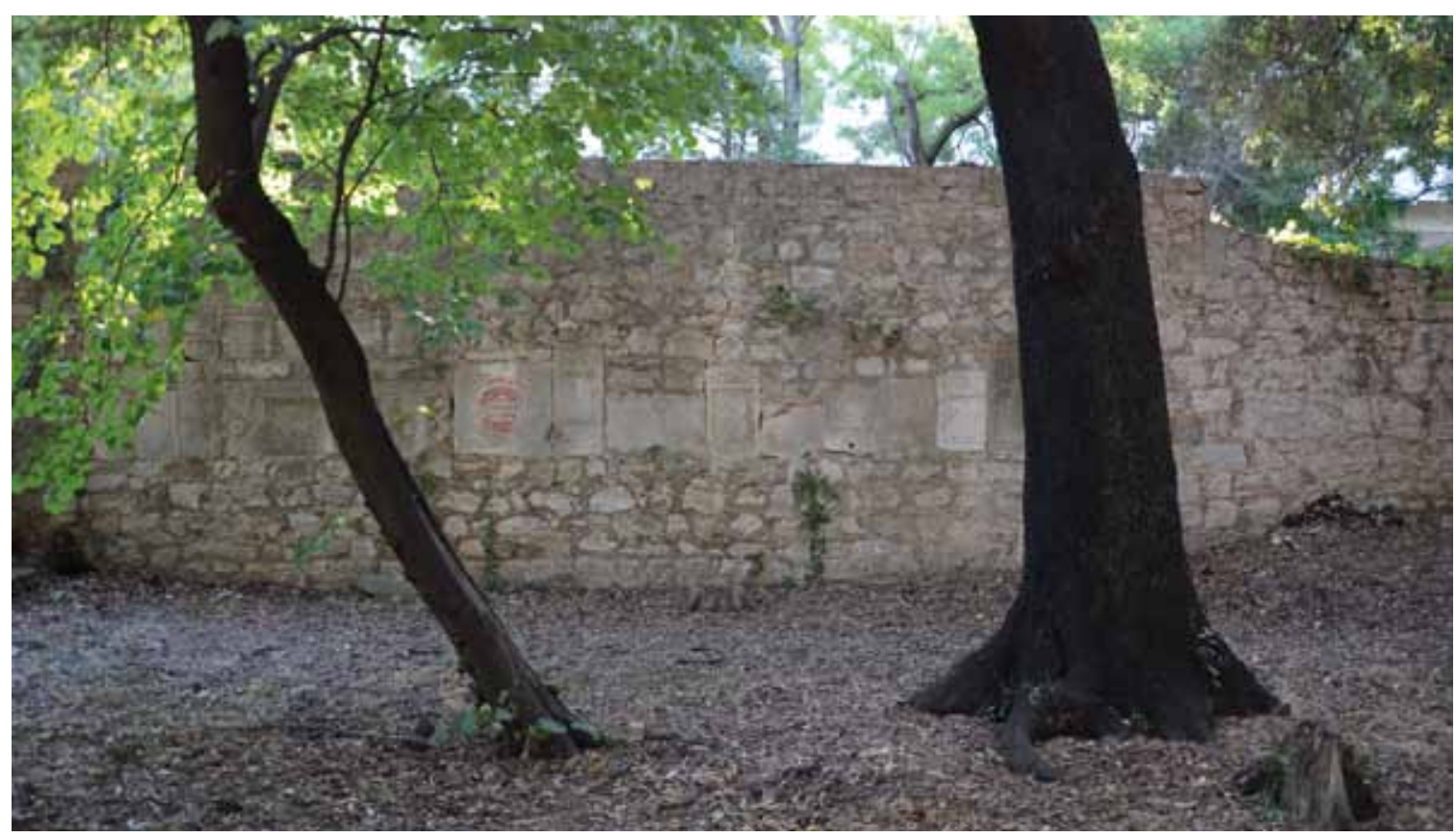

Probu pronađena je prilikom gradnje kuće Capogrosso u Splitu (sjeverni dio Dioklecijanove palače), a potom je uzidana u njezin sjeverozapadni ugao u razizemlju. ${ }^{14}$ Ta se lokacija, nažalost, pokazala neprikladnom, jer je u novije doba ispred spomenika instaliran koš za otpatke pa je, osim što je ovaj važan spomenik slabo primjetan, često i zaprljan otpacima i drugim sadržajima (sl. 4). Oba spomenuta natpisa bila su iskorištena u sekundarnoj uporabi, no njihovo podrijetlo nije nužno morala biti Salona, već su mogli pripadati naselju koje je preslojila Dioklecijanova palača.

Interes za donošenjem epigrafskih spomenika iz Salone u Split, ali ne kao građevinskog materijala, nego sa svrhom da ih se prikuplja, proučava i prezentira javnosti datira iz doba rane renesanse. Naime, u 15. i 16. stoljeću među plemstvom i obrazovanijim ljudima u Europi postalo je vrlo popularno skupljati predmete koji su potjecali s antičkih lokaliteta te su se počele osnivati prve zbirke-preteče današnjih muzeja. Kao posebno cijenjena vrsta svjedočanstava antike bili su natpisi. Ondašnji skupljači i intelektualci vrlo brzo su shvatili da su natpisi vrlo čvrsta veza s antikom, jer sadržavaju izravne podatke o periodu od prije više od tisuću godina. U Papalićevoj palači (današnji Muzej grada Splita) u sjevernom dijelu Palače, krajem 15. i početkom 16. st. nastala je prva epigrafska zbirka na ovim prostorima, a koja je prikupljena zaslugom splitskog plemića Dmine Papalića i poznatijeg mu prijatelja Marka Marulića. No vrlo brzo, već u 2. pol. 16 st. ovi su se kameni spomenici počeli raznositi na razne strane, gdje su dobivali novu svrhu: Pet ih je danas u Arheološkome muzeju u Splitu ${ }^{15}$, neki su odneseni u Italiju ${ }^{16}$, neki su postali građevinski materijal u samoj Papalićevoj palači ${ }^{17}$, jedan je spomenik završio u podu kora splitske

14 CIL III 8707.

15 CIL III 1935, 1961, 1979, 2096, 2551.

16 CIL III 131*, 1933, 2475, CIL XVI 38.

17 CIL III 1981. Natpis je danas ugrađen u stepenište stražnjeg dvorišta Muzeja grada Splita. 
prvostolnice $^{18}$, jedan je sarkofag iskorišten kao grobnica i ugrađen u pod crkve sv. Klare ${ }^{19}$, dok se za većinu danas ne zna gdje su (Demicheli 2015a: 146). Izgledno je da su i oni završili kao građevinski materijal koji će se s vremenom možda i pronaći u procesu istraživanja i obnove stare gradske jezgre. Kao posebno zanimljiv primjer reciklaže natpisa iz Papalićeve zbirke spomenut ću nadgrobnu stelu iz 1. st. kojoj je u doba humanizma otučen originalni natpis i uklesan novi. Taj je novi tekst pokušaj imitacije antičke epigrafske tradicije, no sadržaj mu je u raskoraku s vrstom spomenika te je jasno da se radi o izmišljenom natpisu (sl. 5). Izmišljanje novih, odnosno falsificiranje natpisa bila je navada raširena u to doba u Europi, jer su se i sami humanisti željeli prikazati što učenijima opisujući natpis kakav prije njih nitko drugi nije interpretirao.

Dvadesetak epigrafskih spomenika ugrađeno je u zid perivoja obitelji Garagnin-Fanfogna (sl. 6) u Trogiru početkom 19. st. zaslugom konzervatora Gianluce Garagnina koji je želio na ovaj način prezentirati spomenike pronađene u istraživanjima Salone (Babić 2016: 272-273). Ovo je danas ujedno i jedan od najzanimljivijih primjera skupne ne-muzejske prezentacije epigrafskih spomenika s obzirom na to da su u javnome prostoru.

Za mnoge se natpise ni ne zna da su iskorišteni kao građevinski materijal, jer inkorporacija ovih spomenika u građevine ni na koji način ne sugerira njihovu stvarnu prisutnost u njima. Takvi primjerci ostanu nepoznati sve do faze rušenja, restauracije ili konzervacije nekog objekta te ih se s pravom može nazvati kriptospolijima. Kao primjer navest ću nekoliko natpisa pronađenih izvan Salone, odnosno u Trogiru i na otoku Braču, gdje su pronađeni vrijedni epigrafski spoliji. Antički su ulomci u Trogiru korišteni u gotovo svim povijesnim razdobljima, što se može vidjeti na mnogim fasadama postojećih kuća i crkava. Pri arheološkim se istraživanjima uvijek naiđe na zidove starije epohe trogirskog urbanizma, bilo da se radi o helenističkom, rimskom ili kasnoantičkom razdoblju. Upotreba spolija na prostoru Trogira javlja se u kasnoj antici, a jedan od izuzetnih primjera je zavjetni natpis sa spomenom božice Salacije koji je pronađen u kasnoantičkome zidu (Demicheli 2008). Kanal za otpadne vode unutar benediktinskog samostana sv. Nikole građen je u 19. stoljeću, a prilikom njegova istraživanja pronađeni su vrijedni antički spoliji (Kovačić 1994: 61-63). Za jedan od natpisa pronađenih kao poklopnica kanala ustanovljeno je da se radi o ulomku spomenika koji se spaja s natpisom pronađenim u 60-ak kilometara udaljenom Skradinu, gdje je bio izvorno i postavljen. Očito je da je ovaj dio monumentalnog spomenika kao građevinski materijal bio donesen iz Skradina, a njihovim je spajanjem otkriven bitan podatak o juridičkom konventu u Skardoni u drugoj pol. 1. stoljeća (Demicheli 2015b).

Kao primjer navodim i natpise pronađene u predromaničkoj crkvi sv. Duha u Škripu na Braču. ${ }^{20}$ Tek fizičkim rastavljanjem zidova i podova utvrđeno je njihovo postojanje, što navodi na opravdanu pretpostavku da se još mnogo antičkih natpisa nalazi ugrađeno u raznim vrstama objekata, a čija će se prisutnost potvrditi tek nakon njihova urušavanja, uklanjanja, sanacije ili restauracije. Na ovaj se način mogu sagledati i antički sarkofazi iskorišteni za kasnije ukope koji su uloženi u pod crkve te se nije vidjelo da se radi o prenamijenjenim antičkim sarkofazima. Takva je situacija otkrivena pri istraživanju crkve sv. Klare u Splitu, no o takvim će primjerima biti više riječi u narednom tekstu.

Vjerojatno najbogatiji primjer ugradbe spolija dosad otkriven na srednjodalmatinskom području pronađen je na poluotoku Vranjicu između Solina i Splita. Mnoge građevine nastale u posljednjih nekoliko stotina godina u Vranjicu imaju uzidane antičke spolije, no ono što svojom količinom sekundarne uporabe najviše fascinira su spoliji pronađeni na vranjičkoj obali. Na njih je već Bulić ukazivao, koji je svojedobno dao izvaditi tri sarkofaga koja su se nalazila u moru, a razmjer ove ranosrednjovjekovne građevinske intervencije spoznao se tek stotinjak godina poslije. U za-

\footnotetext{
18 CIL III 2654.

19 CIL III 2584. Natpis je izložen u tzv. podrumima Dioklecijanove palače.

${ }^{20}$ Crkva je nastala najvjerojatnije na ostacima hrama posvećenog Velikoj Majci. Natpisi su neobjavljeni.
} 
SI. 7: Portretna stela (CIL III 2491) ugrađena kao nadvratnik u Gašpinoj mlinici u Solinu (izvor: http://solin-info. com/hr/znamenitosti/solin-danas/gaspina-mlinica/).

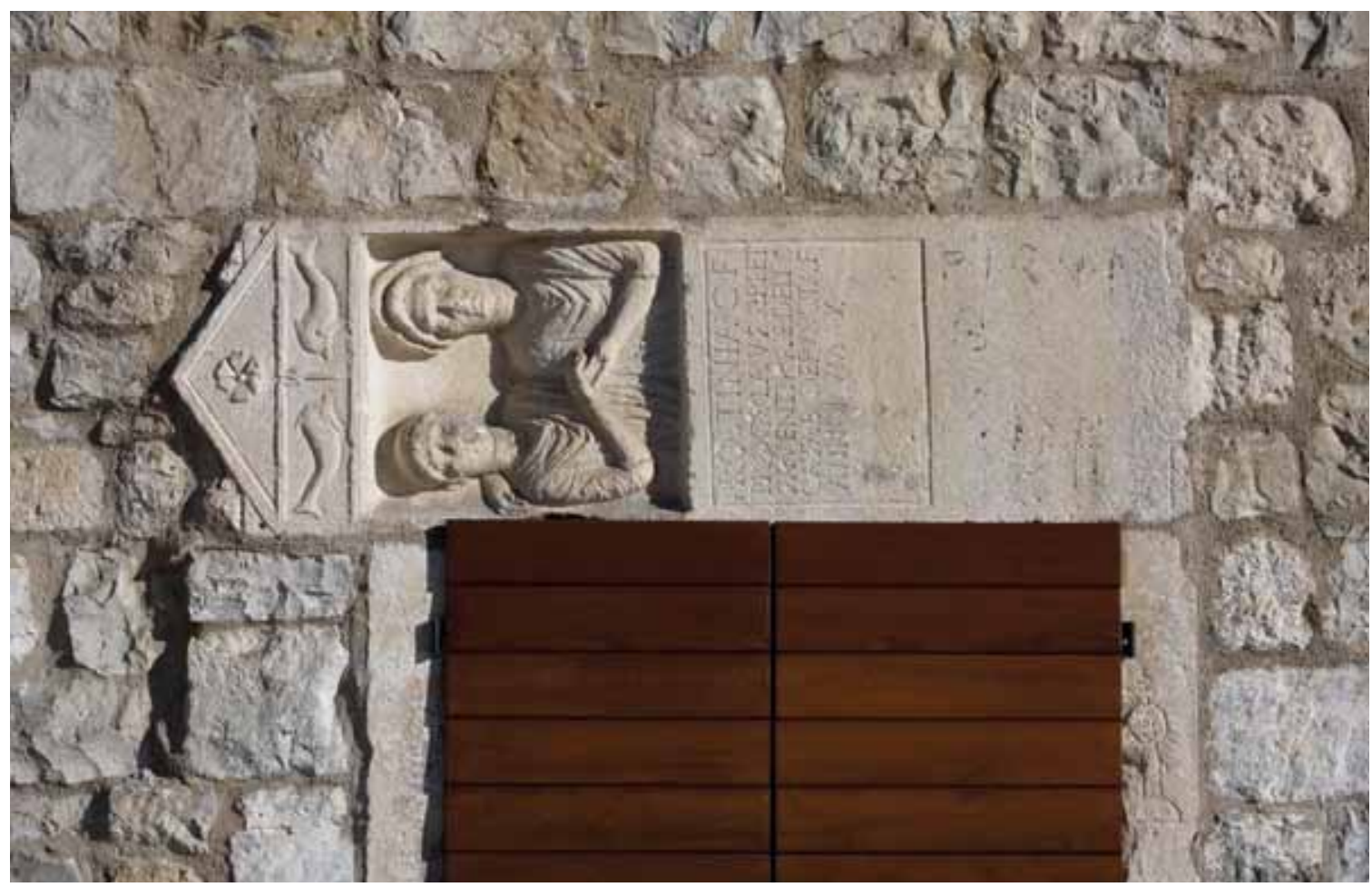

štitnim je istraživanjima otkriveno više stotina kamenih ulomaka koji su u ranome srednjem vijeku iskorišteni za konsolidaciju obale poluotoka (Radić-Rossi 2008; Vodička Miholjek 2008; Skelac \& Vodička 2009). Kako je tek dio materijala mogao biti izvađen, vjerojatno se radi o tisućama kamenih ulomaka koji još i dalje stoje ukopani oko poluotoka. Natpisi koji su ondje pronađeni mogu se datirati od helenizma do 6. stoljeća, a čini se da je materijal za ovu građevinsku intervenciju bio donesen s nekropole, ranokršćanske crkve i vjerojatno kakvog gospodarskog zdanja. S ovih istraživanja potječe i natpis na sarkofagu koji je dosad najpreciznije datirani antički epigrafski spomenik iz Dalmacije (Demicheli \& Demicheli 2018).

Od ostalih pojedinačnih svjetovnih građevina spomenut ću solinske mlinice koje danas uglavnom više ne postoje, ali u koje je također bilo ugrađeno nekoliko natpisa. Na nedavno restauriranoj Gašpinoj mlinici kao nadvratnik ostala je ugrađena lijepa stela s natpisom..$^{21}$ Iako joj je primarna funkcija stabilni arhitektonski element no, kako se ujedno radi i o portretnoj steli većih dimenzija, koja vizualno dominira ovim dijelom pročelja mlinice, pretpostavljam da se graditelj povodio i za dekorativnim efektom ove interpolacije (sl. 7). Iako manjih dimenzija, no na vrlo pomno odabrano mjesto postavljena je rimskodobna stela klesana grčkim alfabetom $^{22}$ ugrađena sa zapadne strane mosta preko rijeke Jadro koji vodi do Gospina otoka. Utvrda Klis građena je od antike do 19. stoljeća, a pri nadgradnjama je konstantno recikliran materijal prijašnjih razdoblja. U nedavnim istraživanjima jednog njezinog dijela pronađeni su desetci antičkih kamenih ulomaka među kojima je bilo i fragmenata natpisa. Možda je upravo njihova fragmentiranost rezultat konstantne reciklaže ovih komada.

${ }^{21}$ CIL III 2491.

22 CIL III 14695. 
Natpisi u privatnim kućama u 18., 19. i 20. st.

Praksa ugradbe antičkih natpisa u stambene objekte ne pripada samo davnim vremenima, kada se ovi spomenici uglavnom nisu razmatrali kao dio kulturne baštine koji bi trebalo zaštititi i adekvatno prezentirati. Odnos prema antičkoj baštini nije nikada bio jednostran: za neke su kameni spomenici predstavljali (za neke, nažalost, i dalje) tragove poganstva koje treba uništiti; za druge, pak, svjedočanstva o antici koje treba sačuvati, dok je nekima kameni spomenik bio samo kamena građa koja se može iskoristiti u razne svrhe. Ovom bi se trećom kategorijom mogli opisati stanovnici Solina na koje se u drugoj pol. 18. st. žalio padovansko-venecijanski opat i putopisac Alberto Fortis. On je, naime, prisustvovao trenutku dok je neki seljak pilio četiri spomenika kako bi od njih napravio građevinski materijal pogodnog oblika. Fortis dodaje kako su mnogi dijelovi drugih spomenika već bili ugrađeni u kuću tog istog čovjeka (Fortis 2004: 178). Ne uspjevši ih otkupiti, Fortis je ipak uspio prepisati njihove tekstove, iz kojih pro-

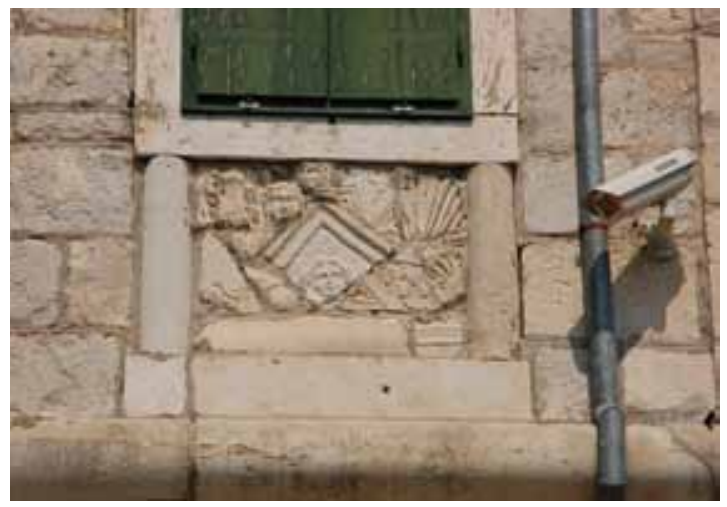

SI. 8: Detalj na građevini kompleksa Tusculum u Saloni s ugrađenim antičkim spolijima (fotografirao: D. Demicheli).

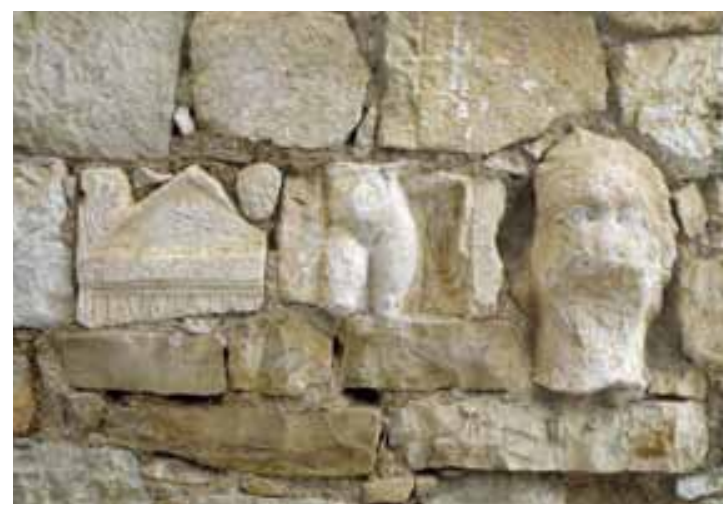

SI. 9: Spoliji u zidu u solinskom naselju Barišići (fotografirao: I. Matijević).

izlazi da su stele pripadale vojnicima VII. legije, a tri od četiri imale su portretne prikaze. ${ }^{23} \mathrm{Za}$ neke se dijelove točno zna gdje su bili uzidani, dok se neki spomenici smatraju izgubljenima. ${ }^{24}$ Iako je, dakle, i prije postojao običaj ugrađivanja antičkih spolija u fasade privatnih kuća, ovaj se običaj od sredine 19. st. može dijelom povezati i s nastojanjima splitskog arheologa i konzervatora Francesca Carrare. On je, istražujući u Saloni, sugerirao mještanima da ono što pronađu tijekom obrađivanja zemlje u Saloni ugrade u svoje kuće te su se na taj način sačuvali brojni natpisi, ulomci skulpture i reljefi (Duplančić 2015: 194). Kao podatak o tome da je iskorištavanje antičkih kamenih spomenika bilo često i uobičajeno pri gradnji na solinskome području govori i citat njemačkog putopisca Theodora Schiffa koji je, prolazeći kroz Solin u 2. pol. 19. stoljeća, ovako zapisao: Skoro u svakoj kući ima mramornih reljefa, rimskih i grčkih natpisa često i naopako ugrađenih, a preokrenuti mramorni sarkofazi služe seljacima kao kameni stolovi ispred kuća (Schiff 1997: 61). Kao potkrijepa ovome citatu svjedoče i opisi o mjestu na kojem su zabilježeni natpisi na području Solina, Splita, Trogira ili Klisa objavljeni u glasovitoj zbirci Corpus inscriptionum Latinarum. Naime, kod mnogih natpisa stoji komentar da se nalaze in aedibus (npr. Šperac, Parać, Gašpić, Plazibat, Carminatti itd.), odnosno u kući neke obitelji. Većina

23 Radi se o natpisima CIL III 2014, 2022, 2040 i 2041.

24 Više o potrazi za ulomcima ovih stela v. Maršić 2010. Naknadno su ustanovljena dva uredno ispiljena dijela natpisa koji su pripadali navedenim stelama (CIL III 2040 i 2041), a nalaze se u vrtu kompleksa Tusculum u Saloni. Nekoć su bili uzidani u kuću Parać u Solinu. 
starih kuća na ovdje opisanom prostoru danas više ne postoji, no natpisi su uglavnom dospjeli u Arheološki muzej u Splitu. Nastavak prakse ugrađivanja spomenika u 19. stoljeću, može se vidjeti kod don Frane Bulića koji je naložio da se pri gradnji kompleksa zgrada poznatijeg kao „Tusculum“ u Saloni ugrade brojni kameni antički i ranokršćanski ulomci bez natpisa koji su pronađeni u Saloni i koji su izvađeni iz zvonika splitske katedrale sv. Duje krajem 19. stoljeća (sl. 8).

Mnogi su epigrafski spomenici, posebno stele, svojim oblikom vrlo pogodni za kasniju ugradbu, posebice na vanjske zidove kuća. Naime, na taj način upotrijebljena stela često ima dvojaku funkciju. Prva je praktična, odnosno ekonomična, jer se radi o već obrađenom kamenu kojemu je pet od šest ploha zaravnjeno, dok je tek prednja strana spomenika s natpisom isklesana u plićem reljefu te ju je najlakše uzidati s tom stranom prema van. Tako postavljen kamen s natpisom može imati i dekorativnu funkciju, o čemu zorno svjedoče pažljivo birana mjesta na kojima su spoliji ugrađeni na brojnim, još dandanas vidljivim kućama na području Splita, Solina,

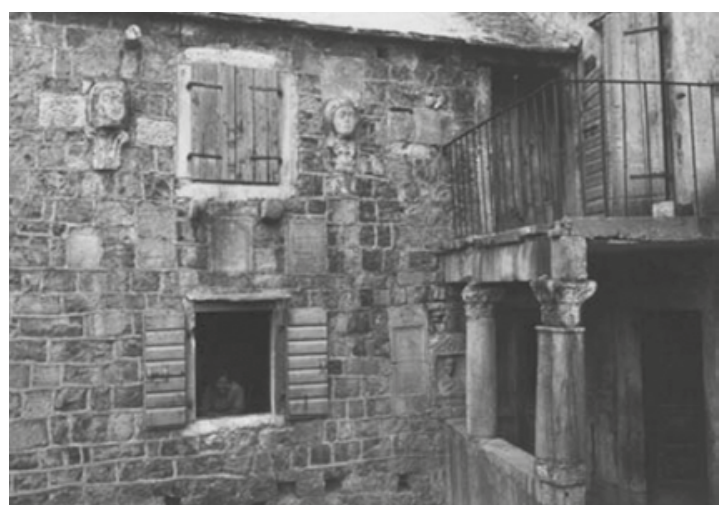

SI. 10: Dio antičkih spolija uzidanih u kuću Benzon u Vranjicu (Fototeka Konzervatorskog odjela u Splitu).

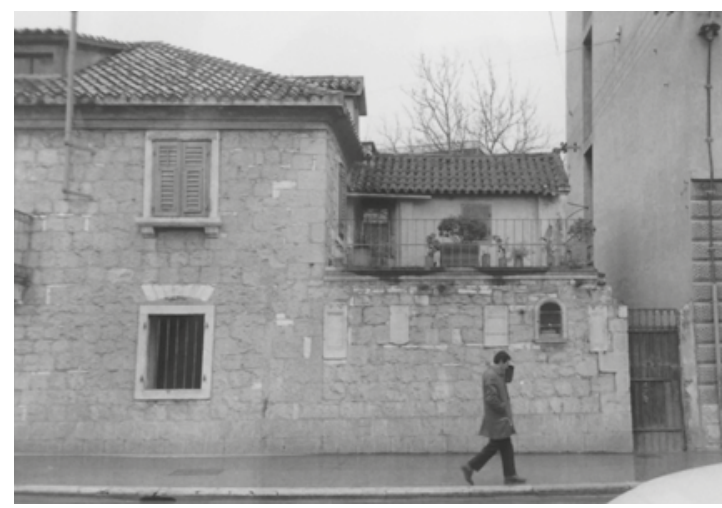

SI. 11: Dio epigrafskih spomenika uzidanih u kuću Katić u Splitu prije njezina rušenja (Fototeka Konzervatorskog odjela u Splitu).

Vranjica, Kaštela, Trogira i drugih mjesta ovoga područja. Kao lijepe primjere ovako ukrašenih vanjskih dijelova kuća spomenut ću kuće u solinskim predjelima Paraći i Barišići (sl. 9), kuću Benzon u Vranjicu (sl. 10), kuću Šperac u Solinu, Geremia-Zlendić kuću u Splitu i kuću Katić (sl. 11) u Splitu. Sve ove kuće, osim epigrafskih spomenika, imaju ili su imale ugrađene i druge vrste antičkih spomenika: ulomke skulpture, reljefe, dekorativnu plastiku i sl. Kuća Benzon u Vranjicu ima ugrađenih 47 antičkih spolija, od čega je 15 natpisa (Švonja 2014). Sklop kuća u solinskim Paraćima, naselju koje se razvilo iznad sjeverozapadnog dijela salonitanskih bedema, ima na desetke uzidanih spolija (Jeličić-Radonić \& Pereža 2010; Matijević 2014). U blizini Paraća nalazila se i kuća Mikelić, srušena 1987. godine, a iz koje su izvađeni spoliji nabavljeni za Arheološki muzej u Splitu (Duplančić 2015: 192). Kuća Geremia-Zlendić (Carminatti), u splitskom kvartu Dobri, danas ima pet natpisa i tri reljefa, vrlo skladno posloženih (Cambi 1990; Barišić \& Marinković 2011). Za spomenute građevine antički je materijal vrlo vjerojatno pronađen u blizini njihove izgradnje, no posebna je zanimljivost kuća Katić (tzv. kuća Očenaša) koja se nalazila u širem centru Splita. Sagrađena je nastojanjima župnika don Ante Katića, koji je na vanjske zidove kuće ugradio sedamnaest antičkih, uglavnom epigrafskih spolija (svi iz Salone), a dio podova u unutrašnjosti kuće pokrio je mozaicima koji su izvađeni iz gradske bazilike u Saloni. ${ }^{25}$ Danas je ovakav građevinski pothvat u pravilu nemoguće izvesti, jer bi bio u potpunoj

${ }^{25}$ Nakon rušenja zgrade sav je antički materijal pohranjen u Arheološkome muzeju u Splitu. 
SI. 12: Stela Gaja Laberija (CIL III 2722) uzidana u pročelje kuće Perković u Sinju (fotografirao: D. Demicheli).

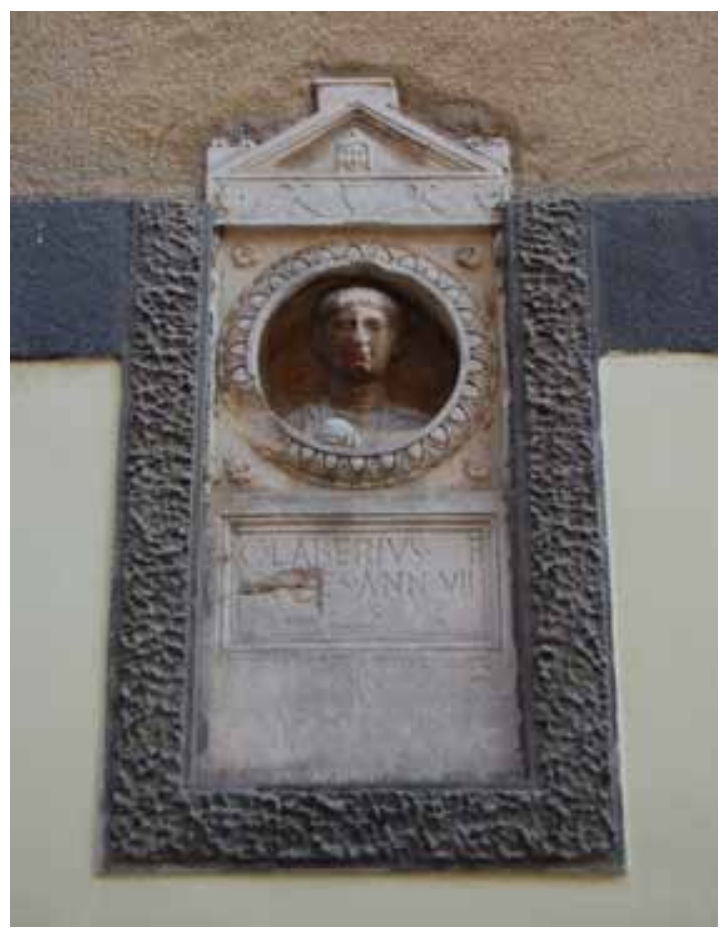

SI. 13: Portretna stela (CIL III 2398) uzidana u kuću Nikšić u Splitu (fotografirao: D. Demicheli).

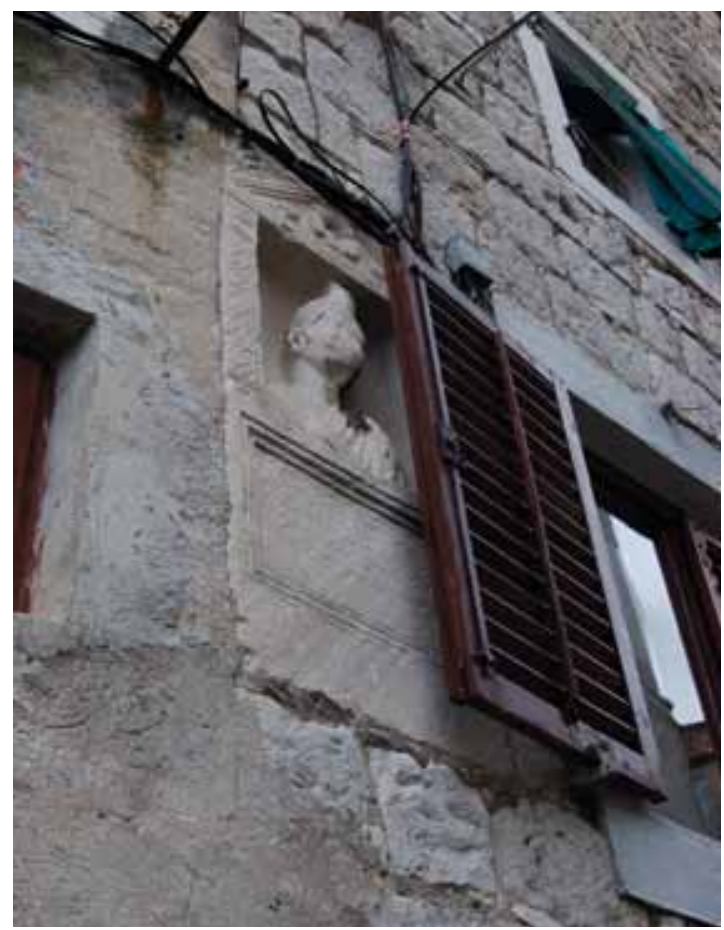

suprotnosti sa zakonom o zaštiti kulturnih dobara. S druge strane, u dogovoru s nadležnim konzervatorskim uredom, ponekad se odobrava ugradba antičkih natpisa u vanjske dijelove zgrada, ali koje nisu privatne kuće. ${ }^{26}$ Kao izrazit primjer dekorativne ugradbe stele $u$ fasadu kuće još ću spomenuti i jedinstveni nadgrobni spomenik dječaka Gaja Laberija (C. Laberius) koja se nalazi u kući Perković u Sinju ${ }^{27}$ (sl. 12).

Ponekad je ovakav graditeljski postupak rezultat pronalaska kamenog spomenika prilikom kopanja temelja za gradnju kuće te se njegovom ugradbom ispunjavaju više namjena odjednom: funkcionalnu i dekorativnu, ali se ovim činom i šalje društvu određena poruka o važnosti i starosti mjesta nad kojim je građevina nastala kao i možebitna poruka nastojanja vlasnika kuće da ga se na taj način percipira kao nekoga tko drži do baštine. Moguće je da su upravo ti razlozi naveli graditelja kuće Nikšić na splitskome Lučcu da ugradi veliku portretnu stelu s natpisom na istočnu fasadu svoje kuće (sl. 13).

Kako spomenike na fasadama uglavnom promatramo iz današnje perspektive kao zanimljive dekorativne detalje, treba biti oprezan pri determiniranju tih komada. Treba uzeti u obzir da neki od njih izvorno nisu bili vidljivi jer su bili prekriveni žbukom. Danas je situacija malo drukčija, pa se u pravilu, kada se tijekom restauracije neke građevine naiđe na spolije ispod sloja žbuke, oni ostave vidljivima. Kao primjer navodim žrtvenik u uredu trogirskog Konzervatorskog odjela.

\footnotetext{
${ }^{26}$ Najbolji primjer za to u novije doba su natpisi koji su bili pronađeni tijekom istraživanja i obnove crkve sv. Andrija de fenestris. Jedan od njih ugrađen je u zid dvorišta današnjeg Etnografskog muzeja u Splitu, koji je nastao preuređenjem spomenute crkve i samostanskog sklopa do njega. Kao drugi primjer spomenut ću dva ulomka nadgrobnih natpisa koji su nedavno ugrađeni u obnovljeni ogradni zid crkve sv. Jere u Pučišćima na Braču.

27 CIL III 2722=9729. Spomenik je, kako se čini, podrijetlom s Garduna.
} 
Nadgrobni su se spomenici ponekad nanovo upotrebljavali za istu svrhu, odnosno sam bi se spomenik ili njegovo natpisno polje preradilo čime bi se naznačilo da pripada nekoj drugoj osobi. Poznata je manja stela iz Salone koja ima nadgrobne natpise uklesane s obje strane ${ }^{28}$, a nastali su u različito vrijeme tijekom 3. st. Na steli pronađenoj u rijeci Žrnovnici istočno od Splita također se s obje strane vide natpisi, a oba vjerojatno pripadaju također 3. stoljeću (Matijević 2006: 147-149). Zanimljiv primjer pruža i nadgrobna stela pronađena u Saloni, a koja na poleđini ima tragove ranijeg natpisa uklesanog na grčkome jeziku. ${ }^{29}$ Pojedinci u kršćanskom razdoblju Salone očito nisu imali problema s korištenjem poganskih spomenika čak ni za osobnu potrebu. Ovakva je pojava najčešće vidljiva kada se naknadno fizički intervenira u izvorni izgled spomenika, npr. kada se otkleše tekst starijeg natpisa te se na to mjesto ukleše novi koji ima kršćanska obilježja. Nema sumnje da su mnogi pokojnici zauzeli mjesto koje im nije pripadalo u nečijem tuđem sarkofagu, ali takve je intervencije vrlo teško dokazati. No da su ovakve aktivnosti itekako postojale u kasnoantičkom razdoblju, posredno svjedoče brojni tekstovi kasnoantičkih natpisa na kojima je izrečena pravna zaštita za oskvrnuće nečijeg sarkofaga s namjerom da u nj stave nečije tijelo. U Saloni je tako poznato više od osamdeset natpisa koji predviđaju globu za one koji se budu htjeli ukopati na to isto mjesto. Kod nekih natpisa to izgleda kao svojevrsno upozorenje novčanom kaznom, dok se kod nekih natpisa čini da je ukop u već postojeći sarkofag trebalo uplatiti ili u gradski proračun ili salonitanskoj Crkvi (Salona IV: 52). Premda predviđene novčane globe ovakvog tipa poznajemo još iz ranijega antičkog razdoblja, ova je praksa najbolje dokumentirana tek u kasnoj antici. Zanimljivo je da paralelno s ovom praksom kršćansko stanovništvo Salone uredno iskorištava poganske sarkofage i stele, i to u razne svrhe. Osim što se poganski natpisi koriste pri gradnji crkava, sarkofazi se ponovno iskorištavaju u istu svrhu. U gore opisanom kontekstu spomenut ću upotrijebljeni sarkofag u koji se dao pokopati vojnik Flavije Valerijan (Flavius Valerianus) u 4. st. ${ }^{30}$ Za potrebe njegova ukopa prijašnji je natpis otučen, uklesan je novi, i povrh svega dodan je novčani iznos koji bi trebalo platiti ako se tko bude htio pokopati povrh njegova tijela, a koji je iznosio čak 3 libre zlata! Sarkofazi su se znali i više od dvaput upotrebljavati. Od jednog takvog sarkofaga iz Šuplje crkve ostala je samo prednja stranica s natpisima. Radi se o sarkofagu koji je napravljen najvjerojatnije krajem 2. ili početkom 3. stoljeća, nakon čega je sredinom 5 . stoljeća natpis otklesan i uklesan je novi, za pokojnika iz reda niže crkvene službe, ostijarija. Uskoro je još jedan natpis dodan u novoizrađeno polje pored glavnog natpisnog polja za još jednog ostijarija, a u kasnijem je periodu ovaj sarkofag razbijen te je njegova prednja strana poslužila kao poklopnica srednjovjekovnog groba (Sanader \& Demicheli 2017). Danas je spomenik pohranjen u muzeju, što je opet na neki način njegova nova upotreba. Valja još spomenuti i jedan specifičan vid korištenja nadgrobnog spomenika na Manastirinama u Saloni: radi se o preradi poganske nadgrobne are koja je izdubljena i pretvorena u sanduk dječjeg sarkofaga, a nad kojim je dodan poklopac sa znakom križa (Cambi 2010: 73).

U srednjemu vijeku nastavljeno je iskorištavanje poganskih sarkofaga za naknadne kršćanske ukope. Neki su sarkofazi bili lišeni svojih poganskih obilježja, dok neki imaju do dandanas gotovo posve sačuvan izvorni oblik. Kao primjer takvog sarkofaga spomenut ću onaj pronađen na starohrvatskom lokalitetu Rižinice između Solina i Klisa. Sarkofag je u jako dobrom stanju, osim natpisa i reljefnih ukrasa na tri strane sanduka sarkofaga, poprilično su sačuvana i dva portreta isklesana $\mathrm{u}$ akroterijima poklopca sarkofaga. ${ }^{31} \mathrm{U}$ temeljima trogirske crkve sv. Sebastijana pronađeni su antički sarkofazi u ostacima romaničke kapelice. Bili su u sekundarnoj

28 CIL III 2304 i CIL III 2569. Stela je u Muzeju grada Trogira.

${ }^{29}$ CIL III 2173.

30 Salona IV, br. 407.

31 Sarkofag je neobjavljen. 
SI. 14: Epigrafski spoliji u srednjovjekovnome grobu u Šupljoj crkvi u Solinu istraženih 1931. god. (Fototeka Konzervatorskog odjela u Splitu).

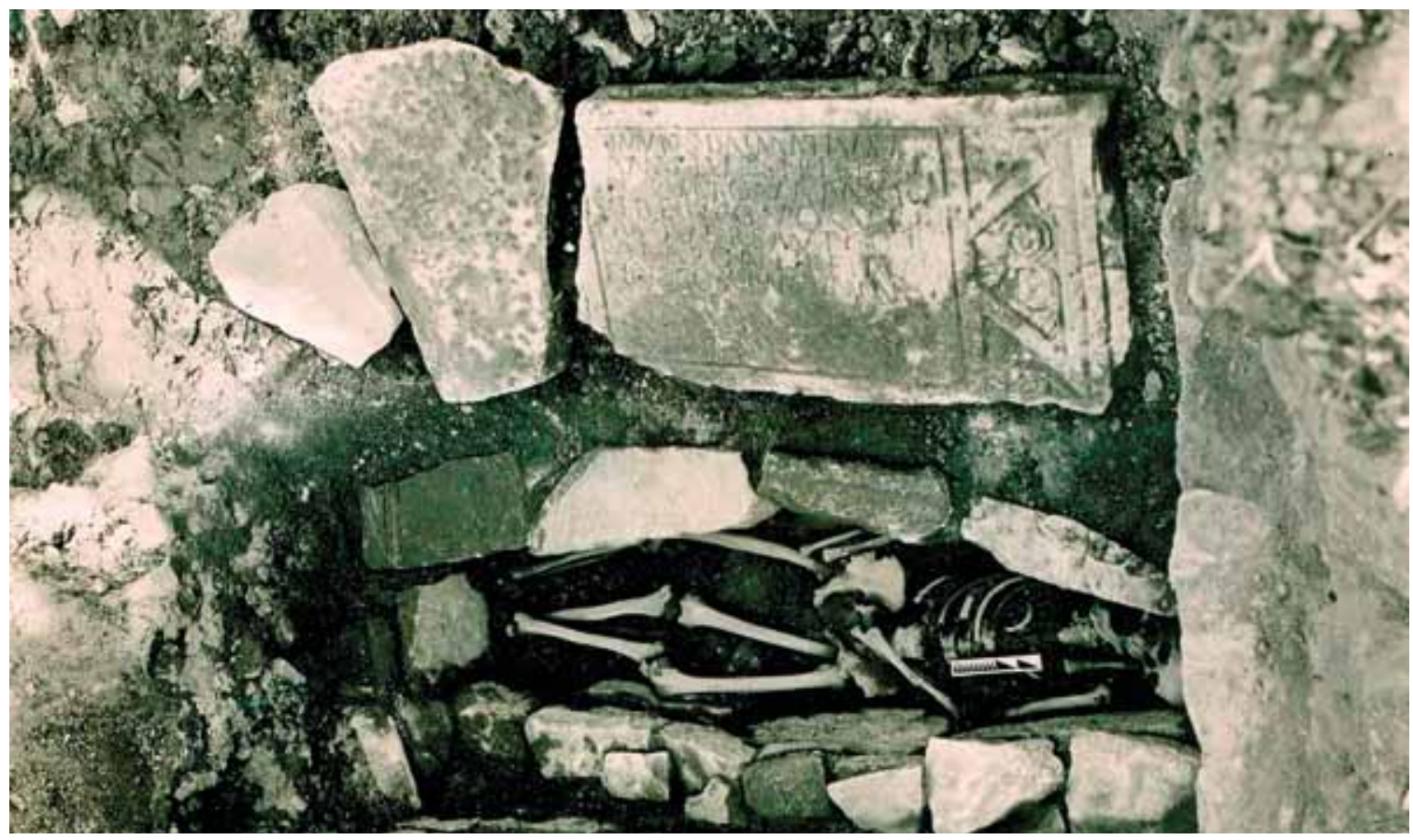

upotrebi, no djelomično su i preinačeni. Jednom je sarkofagu još uvijek vidljiv čitavi natpis, dok je drugome otučen, ali su na njemu vidljivi slabi tragovi prijašnjih slova.

Ovakva se praksa zadržala i u razdoblju nakon srednjega vijeka, kada nailazimo na razne slučajeve iskorištavanja antičkih sarkofaga. Kako je ukop u sarkofagu oduvijek bio vrlo skupa investicija, ne čudi da su se za ovakav potez odlučivali i pripadnici bogatijeg društvenog sloja. Trojica splitskih kanonika iz 15. i 16. stoljeća, Ilija Babalić, Marinello Ricius i Jakov Selimbrić su za svoje grobno mjesto odabrali antičke sarkofage. Sarkofazima je prethodno otučen originalni natpis i uklesani su novi (Duplančić 2014). Zanimljivu upotrebu jednog te istog sarkofaga kroz razna povijesna razdoblja nalazimo i na antičkom sarkofagu čiji je natpis zajedno s ukrasom $u$ obliku tabula ansata otučen početkom 4. st. te je na njegovo mjesto uklesan novi. Sarkofag je u renesansi bio jedan od epigrafskih spomenika izloženih u zbirci Dmine Papalića, a opet je u 17. stoljeću iskorišten kao grobnica u podu crkve sv. Klare u Splitu (Demicheli 2015b).

Kao posebnu skupinu recikliranih nadgrobnih natpisa spomenut ću one koji su služili pri gradnji kasnijih grobova i grobnica. Ovakva je uporaba posebno vidljiva u kasnoj antici i srednjemu vijeku, kada su se poganske stele, tituli ali i dijelovi razlomljenih sarkofaga znali ponovno koristiti u ove svrhe. Stele su zbog svoje forme najpogodnije za ugradbu pa su zato najčešće i korištene pri gradnji grobnica. Najbolji pojedinačni primjer onodobne ovakve prakse je grobnica pronađena u Dugopolju koja je čitava bila izgrađena od 7 velikih stela. Grobnica je nastala krajem 3. ili početkom 4. stoljeća, dok su stele (uglavnom vojničke) iz 1. stoljeća (Cambi 1994). Na ranokršćanskim grobljima Manastirine i Kapljuč u Saloni pronađeno je više zidanih grobnica (tipa a pozzetto) za čiju su gradnju, ponekad kao vrata grobnica, iskorištavane stele i tituli, odnosno njihovi ulomci. Jedan od boljih primjera za to je nadgrobni natpis Konstancije koji je podignut u 4. stoljeću. Natpis je zanimljiv jer ima i poganska i kršćanska obilježja, a u sekundarnoj je uporabi iskorišten vjerojatno u 5. ili u 6. stoljeću (Rendić-Miočević 2011: 165-166). Na istom je groblju titul legijskog veterana pretvoren u prag za vrata grobnice pri čemu je otklesan dio natpisa. Pri gradnji srednjovjekovnih grobova natpisi su mogli poslužiti 


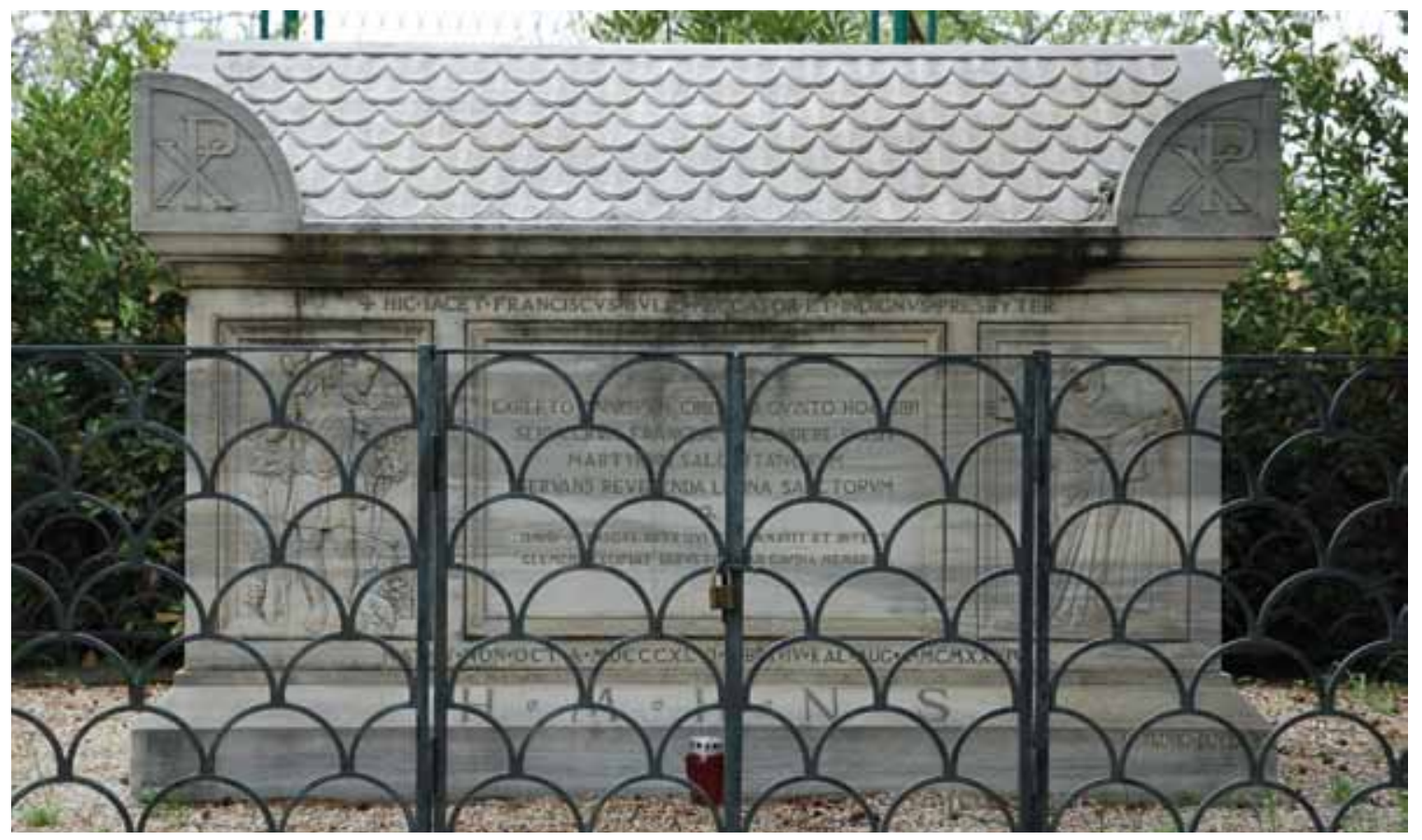

kao materijal za oblaganje grobne rake ili kao poklopnica groba. Takva je situacija dobro dokumentirana na lokalitetu Šuplja crkva u Solinu gdje su prednje stranice sarkofaga s natpisom bile korištene kao poklopnice starohrvatskih grobova (Demicheli 2017) (sl. 14) ili na lokalitetu Klapavice u nešto kasnijem periodu (Jurčević 2007: 252, 263). U istraživanjima ranokršćanskog i srednjovjekovnog groblja kod crkvice sv. Nikole u solinskom naselju sv. Kajo kao spoliji u ranosrednjovjekovnim grobovima pronađena su dva zanimljiva kasnoantička natpisa. Jedan je natpis $^{32}$ na steli mladića Aurelija Valerina (Aurelius Valerinus) koji je umro u carskoj službi na dvoru u Nikomediji, a pronađen je prepolovljen kao poklopnica groba (Rendić-Miočević 1957). Drugi je spomenik nađen u dva dijela i imao je funkciju praga i dovratnika, a radi se o jednom od najzanimljivijih natpisa u kasnoantičkoj Saloni. ${ }^{33}$ Natpis spominje prijetnju da će svako tko bi htio otvarati grob, bio on Rimljanin, Židov, kršćanin ili onaj koji štuje Mane, navući na sebe bijes božanstava (Gabričević 1959). Očito je da se u nekom kasnijem razdoblju netko oglušio na prijetnje, no sam je natpis izvrstan dokaz o suživotu pripadnika raznih vjeroispovijesti u Saloni kasnoga 3. ili ranoga 4. stoljeća.

Jedan od najkasnijih, ali posebno zanimljivih primjera prerade kasnoantičkog sarkofaga u ponovnu namjenu posljednjeg počivališta je sarkofag znamenitog hrvatskog arheologa don Frane Bulića (sl. 15). Radi se o sarkofagu pronađenom u Zviračama pored Trogira koji, doduše, izvorno nije nosio klesani natpis, no za potrebe don Franina ukopa sarkofag je potpuno klesarski prerađen te je na njega dodan natpis (Duplančić 2014: 354-358) ${ }^{34}$. Treba spomenuti da je natpis ustvari parafraza dvaju salonitanskih kršćanskih natpisa u stihu, tzv. carmina epigraphica ${ }^{35}$ te da je don Frane sam odredio koji će stihovi biti iskorišteni za njegov epitaf.

\footnotetext{
32 Salona IV, br. 136.

33 Salona IV, br. 69.

${ }^{34} \mathrm{U}$ citiranom se djelu donosi vrlo zanimljiv historijat nabave i izrade ovog sarkofaga.

35 CIL III 9527 i 9638. Natpis završava tipičnom rimskom formulom o nenaslijeđivanju grobnog mjesta hoc monumentum heredem non sequitur.
} 
Praktički u svakom mjestu na širem splitskom području antički su se natpisi nalazili uzidani u crkve. Već letimičnim pregledom salonitanskih natpisa objavljenih u zbirci Corpus inscriptionum Latinarum jasno je da je veliki broj natpisa bio ugrađen u pročelja i unutrašnjosti crkava. Mnoge stare crkve danas ne postoje pa ne možemo znati ni približno koliko je ovaj običaj uistinu bio prisutan na ovom području, može se sa sigurnošću zaključiti da su se pri gradnji kršćanskih objekata u svakom periodu koristili antički natpisi. Bez obzira na pogansko podrijetlo epigrafskih spomenika, već od ranokršćanskoga razdoblja primjetno je njihovo korištenje pri gradnji crkava. Mnoge su ranokršćanske crkve sačuvane samo do temeljne stope pa se ne može ni ustanoviti gdje su sve spoliji bili ugrađivani. U podovima nekih crkava poganski su natpisi pronađeni s natpisnom stranom prema gore, što bi se moglo i protumačiti kao negiranje poganstva samim gaženjem po natpisu (Babić 2006: 94). Smatram da je ovakva simbolika bila na snazi tijekom kasne antike, no nakon što je kršćanstvo prevladalo i nakon što su svi glavni javni prostori lišeni izrazitih poganskih obilježja, čini se da je kršćanski svijet ranoga srednjovjekovlja postao poprilično indiferentan prema kamenim ostatcima pretkršćanske uljudbe. To se upravo vidi po korištenju spolija, pri čemu smatram da kršćani njihovom ugradbom u crkvenu arhitekturu više potvrđuju svoju ravnodušnost nego eventualni trijumf nad poganskim svijetom. Na nekim bih mjestima u kasnijem razdoblju bio skloniji interpretirati ugradbu antičkog spomenika kao odraz afirmativnog stava prema antici, kao npr. u samostanu sv. Ante na Poljudu, u samostanu sv. Nikole u Trogiru ili u zvoniku sv. Duje o kojima će nešto kasnije biti više riječi.

Natpisi su u ranokršćanskim crkvama najčešće ugrađivani ako je crkva bila podignuta u blizini poganske nekropole koja je ujedno i izvor kamene građe. To iznimno dobro potvrđuju velike kršćanske bazilike u episkopalnom centru, na Manastirinama, na Kapljuču, u Šupljoj crkvi ili crkva u Klapavicama iznad Klisa i dr. U istraživanjima gradske bazilike u Saloni (tzv. basilica urbana) pronađeno je više desetaka što čitavih što fragmentiranih naknadno iskorištenih epigrafskih spomenika, uglavnom dijelova stela i sarkofaga (Bulić 1912). Većina je natpisa pronađena u ruševinama ovoga kompleksa, dok su neki pronađeni ugrađeni u pod. ${ }^{36}$

Materijal je dijelom vjerojatno pribavljen s dijelova istočne i jugoistočne nekropole čiji su dijelovi ostali unutar novih bedema. Na području lokaliteta Manastirine i Kapljuč, koji su se nalazili iznad sjevernih bedema, već su se otprije nalazile poganske nekropole odakle je uziman materijal za gradnju, bilo samih bazilika, bilo kršćanskih grobnica (Egger 1926; Brøndsted 1928). Uz Šuplju crkvu nalazio se dio salonitanske istočne nekropole, dok je uz lokalitet Klapavice postojalo neko manje naselje s nekropolom čiji su dijelovi ugrađeni u ranokršćansku crkvu. U Šupljoj crkvi, najvjerojatnije sagrađenoj u 5. stoljeću, pronađeno je više desetaka natpisa iskorištenih kao građevinski materijal pri gradnji ranokršćanske crkve, a potom i romaničke bazilike sv. Petra i Mojsija (Demicheli 2017). Većina je natpisa izvađena, a nekolicina ih još uvijek stoji ugrađena u narteks ranokršćanske bazilike, kao npr. titul i stela s posvetom poganskim podzemnim bogovima. Ondje pronađeni natpisi većinom su nadgrobnog karaktera, dok je u Klapavicama izbor materijala nešto šarolikiji pa su se ondje osim stela pronašli i žrtvenici (uzeti vjerojatno iz nekog privatnog svetišta) i dva miljokaza, što ukazuje na to da su graditelji posegnuli za građevinskim materijalom s nešto šireg prostora. Miljokazi su sigurno bili uzeti s obližnje magistralne ceste, a jedan je od njih pronađen u svojstvu praga u ranokršćanskoj crkvi (Bulić 1907; Demicheli 2009). Ponegdje se naiđe na spomenik koji pored očitih poganskih obilježja ima naknadno dodan i križ, koji je na taj način simbolizirao pobjedu kršćanstva. Jedan od ljepših primjera za to potječe, doduše, izvan ovdje obrađenog područja, a radi se o miljokazu koji je iskorišten kao stup zadarske crkve sv. Petra Starog, a preko natpisa ima uklesan veliki križ. ${ }^{37}$

\footnotetext{
36 ILJug 2102, 2103.

37 CIL XVII/4, 266. Miljokaz spominje cara Tacita iz 3. st. Zanimljivo je i da je sam prostor nekadašnje crkve doživio promjenu u vidu profanizacije s obzirom na to da se danas u njemu prodaju suveniri.
} 
SI. 16: Jedna od tzv. Dolabelinih ploča (CIL III 3201), nekoć ugrađenih u zvonik sv. Duje u Splitu (fotografirao: T. Seser).

SI. 17: Dio baze za kip cara Karakale (CIL III 14684) pretvoren u romaničku konzolu za zvonik sv. Duje (fotografirao: D. Demicheli).

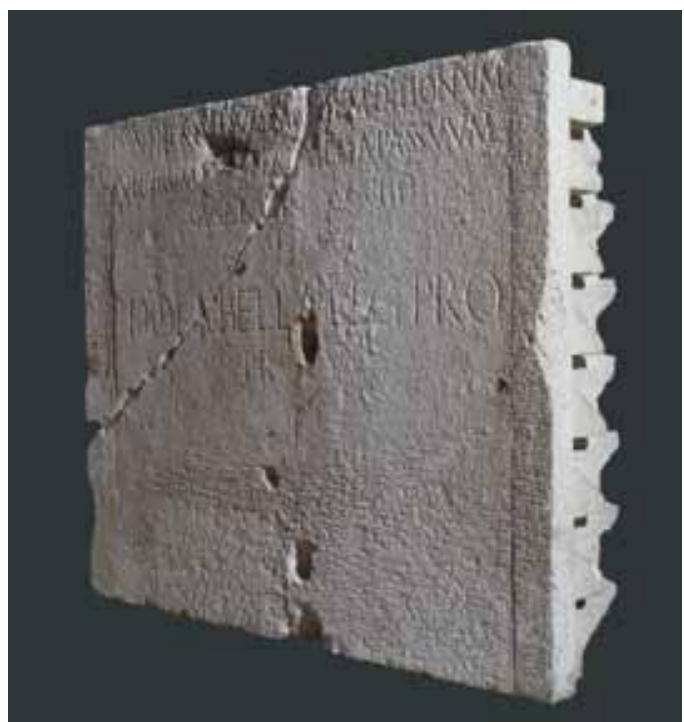

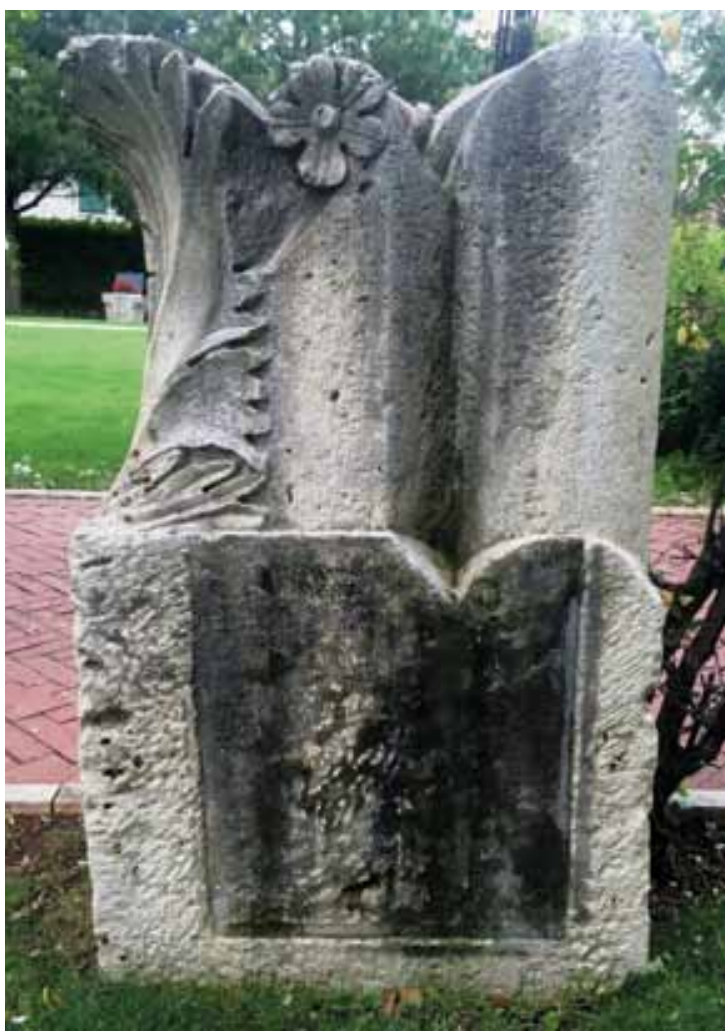

U srednjovjekovnoj crkvi u solinskoj Gradini također je pronađeno više desetaka antičkih spolija, koji su bili u nju ugrađeni među kojima i dosta natpisa koji su bili odneseni s obližnje istočne nekropole (Bulić 1913).

Kasniji primjeri reciklaže natpisa, kako je rečeno, ne bi trebali imati simboličke veze s negacijom poganstva, više s ravnodušnošću ili ignorancijom. Fortis je jednu takvu epizodu opisao na otoku Sustipanac u Pirovačkom zaljevu gdje se s izrazitim ogorčenjem žali na "fratarsko barbarstvo“ zbog razbijanja natpisa za popločenje „bijednog dvorišta“ njihova samostana (Fortis 2004: 108). Radi indiferencije ili neukosti, kao baza oltara crkve sv. Marije u Klisu bila je ugrađena počasna ara dječaka senatorskog staleža Pubija Balzamija Sabinijana (P. Balsamius Sabinianus) ${ }^{38}$, dok je relativno kasno, u prvoj pol. 19. st. kao oltar novosagrađene crkve sv. Kaja u Solinu, iskorišten antički sarkofag s prikazima Heraklovih poslova koji se ondje i danas nalazi (Bulić 1986: 29).

Pravi biser po količini i važnosti antičkih spolija koji su u nj bili ugrađeni svakako su romanički zvonik sv. Duje u Splitu i unutrašnjost same katedrale. Zvonik je temeljito restauriran krajem 19. i početkom 20. stoljeća, a iz njega je izvađena veća količina sekundarno upotrijebljenih antičkih dijelova arhitekture, mramornih oplata, epigrafskih spomenika i jedan reljef s natpisom (Babić 2007). Mnogi ovi komadi naknadno su obrađeni u romaničkim klesarskim radionicama te je njihov originalni izgled doveden gotovo do neprepoznatljivosti. Kao najznačajniji epigrafski spomenici, a ujedno i primjeri naknadne obrade izdvajaju se tzv. Dolabeline ploče, odnosno dijelovi monumentalnog spomenika na kojem su zabilježene građevinske aktivnosti Publija Kornelija Dolabele, carskog namjesnika Dalmacije u vrijeme cara Tiberija (sl. 16). ${ }^{39}$ Nakon što su ovi natpisi pročitani, bilo je moguće ustanoviti vrijeme i rutu gradnje najvažnijih cestovnih komunikacija koje su od Salone vodile k unutrašnjosti provincije. Ploče su bile prepiljene, a s bočnih su strana preklesane i iskorištene kao dijelovi pri gradnji vijenca jednog od katova zvonika. Zanimljiv slu-

38 CIL III 1985=8571.

39 CIL III 3198a, 3198b, 3200, 3201. 


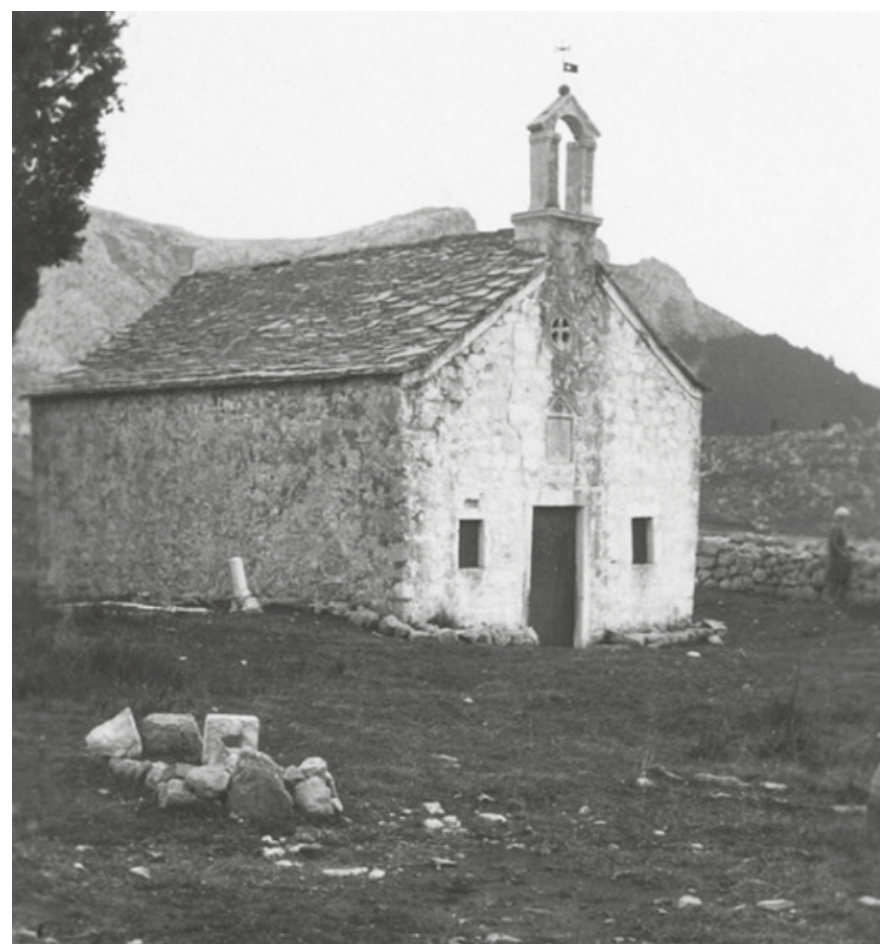

SI. 18: Crkva sv. Ivana Kliškog s ugrađenim nadgrobnim natpisom (CIL III 9187) na pročelju (Fototeka Konzervatorskog odjela u Splitu).

čaj još očitije naknadne intervencije vidi se kod dva arhitektonska ukrasa (dekorativna konzola i greda vijenca, sl. 17) koji su nekoć u Saloni činili cjelinu u vidu počasne baze za kip cara Karakale (Demicheli \& Demicheli 2017) ${ }^{40}$ Na sličan je način kao i prethodno opisani spomenici bio obrađen i počasni natpis carice Faustine. ${ }^{41}$ Dio korištenih spolija u splitskome zvoniku imao je osim svoje utilitarne vrijednosti i onu simboličku u kojoj se zrcali uvažavanje antičke baštine, ali i svijest graditelja da je splitska nadbiskupija nasljednik nekadašnje salonitanske (Babić 2007: 166).

Prema komentarima iz CIL-a, nemali broj epigrafskih spomenika bio je ugrađen u crkvu sv. Arnira u Splitu koja je u međuvremenu porušena. Nakon što su crkve srušene natpisi su uglavnom spašeni i preneseni u muzeje, ali postoji još relativno velik broj crkava na kojima se i danas uočavaju antički natpisi. Vrlo zanimljiv natpis Gaja Orhivija Amempta (C. Orchivius Amemptus) iz 1. stoljeća, uzidan je u jedan od vanjskih zidova samostanskog kompleksa sv. Ante na Poljudu, a u pod same crkve ugrađena je jedna stela. ${ }^{42} \mathrm{U}$ crkvama sv. Križa i sv. Petra u splitskom predjelu Veli varoš ugrađena su tri natpisa, od kojih su dva u podu ${ }^{43}$ dok u vanjskom zidu crkve Gospe od Špinuta u Splitu stoji uzidan ranokršćanski natpis. ${ }^{44} \mathrm{Na}$ vrlo istaknutom mjestu zapadnog pročelja crkve sv. Ivana u Kliškome polju nalazi se uzidan nadgrobni antički natpis, po svoj prilici nastao u 2. stoljeću. ${ }^{45}$ Prema mjestu njegova smještanja iznad ulaznih vrata smatram da je uzidan ne samo kao građevinski materijal, već ima i dekorativnu funkciju (sl. 18). U istoj crkvi, ali u podu, stoji ugrađena prednja strana sarkofaga iz kraja 3. ili ranoga 4. stoljeća (Cambi 2010: 97,

\footnotetext{
40 CIL III 142437 i 14684.

41 CIL III $14243^{6}$

42 CIL III 2500.

43 CIL III 2213, 2443, 2595.

44 Salona IV, 110.

${ }^{45}$ CIL III 9187.
} 
SI. 19: Antička stela prerađena u otvor za milodare i uzidana u južni zid crkve sv. Duha u Splitu (fotografirao: D. Demicheli).

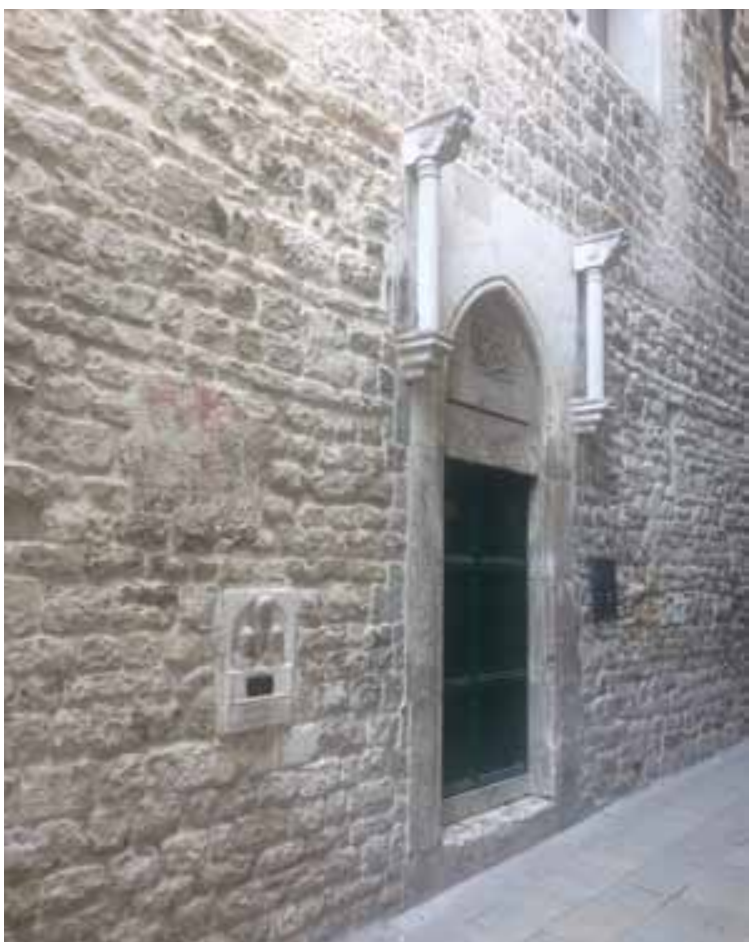

br. 4). Grobljanska kapela crkve sv. Ivana Krstitelja u Mravincima ima ugrađenu antičku stelu u razini očiju prolaznika. Trogirska katedrala sv. Lovre ima ugrađen pri vrhu istočnog lica dio antičkog natpisa koji je sveden na mjere građevnog bloka te ga se može promatrati isključivo kao materijal za gradnju. S druge pak strane, u dvorištu benediktinskog samostana sv. Nikole u Trogiru uzidan je poznati helenistički natpis (Brunšmid 1998: 43-44), no njegova pozicija otkriva namjeru graditelja da natpis bude dostupan pogledu promatrača. U tom se samostanu nalazi i zbirka „Kairos“, prozvana prema najpoznatijem eksponatu, helenističkom mramornom ulomku boga Kaira pronađenom u Trogiru, premda je njegovo podrijetlo najvjerojatnije Grčka ili Mala Azija. Zanimljivo je da je i taj ulomak svojedobno bio u sekundarnoj upotrebi kao kamen kojim se pritiskao poklopac posude za slane srdele. U crkvi sv. Martina u Podstrani uzidana je jedna stela, no ono po čemu je ovo mjesto puno poznatije jest natpis uzidan u ogradni zid sa sjeverne strane crkve. Radi se o natpisu koji je još za svog života dao uklesati vojskovođa Lucije Artorije Kast (L. Artorius Castus) koji je ostvario izuzetnu vitešku karijeru u 2. st. ${ }^{46}$ Pretpostavlja se da je natpis izvorno stajao ugrađen u Artorijev mauzolej, nad čijim je ostacima kasnije sagrađena crkva sv. Martina (Cambi 2014).

Kao posebna vrsta preradbe antičkog spomenika s natpisom izdvaja se stela s portretnim prikazima ugrađena u vanjski zid crkve sv. Duha u Splitu. Radi se o antičkom nadgrobnom spomeniku kojem je otučen originalan natpis, dodan je natpis na hrvatskom jeziku, a antički su portreti izmijenjeni te su gotovo posve lišeni onodobnih stilskih karakteristika (sl. 19) (Cambi 1987). Radi se o jako lijepom primjeru palimpsest reljefa, kakav se može primijetiti i na još jednom primjeru sa splitskog područja: gornji dio antičke portretne stele prerađen je u srednjemu vijeku u lik sv. Ivana Evanđelista i ugrađen u ogradni zid crkvice sv. Jere na Marjanu (Cambi 1997).

46 CIL III 1919. 
U ovu kategoriju ubrajaju se spomenici koji nisu bili ugrađeni u neki dio arhitekture nego su u nekom razdoblju prenamijenjeni kako bi služili pri obavljanju svakodnevnih aktivnosti. Kako je stanovništvo na ovdje opisanom prostoru ranije uglavnom živjelo od rada na polju, kameni su spomenici često bili u vezi s poslovima uzgoja životinja ili prerade plodova. Tako su se kamene urne koristile za čuvanje sira u ulju ili spremanje smokava i oraha (Bulić 1986: 57). Poznato je da su se antički sarkofazi u primorskim krajevima koristili kao kamenice za ulje ili pojilišta za stoku i konje, pa čak i za pranje rublja. Kamenice i pojilišta svojim oblikom odgovaraju sanduku sarkofaga te je ponekad bilo jednostavnije iskoristiti već postojeći sarkofag nego naručivati nove kamene izrađevine. Don Frane Bulić često je od seljaka otkupljivao kamene spomenike pa tako i sarkofage bez natpisa, a plaćao je prema njihovoj zapremnini, dok je posebna tarifa bila za spomenike sa slovima (Duplančić 1986: 321). I poklopci sarkofaga služili su kao pojilišta, o čemu svjedoči don Frane Bulić (Bulić 1986: 57), ali ova se pojava zadržala i u kasnije doba, npr. na Braču. Na ovome je otoku jednom sarkofagu otučeno dno te je ugrađen kao monolitni okvir vrata u predromaničkoj crkvi sv. Mihovila iznad mjesta Dol (Fisković 1981: 124-125). U Saloni je na lokalitetu Oratorij A pronađen sanduk sarkofaga koji je služio kao bazen u koji se ulijevala voda podizana vodeničkim kolom (Mardešić \& Chevalier 2004: 752). Iz komentara u CIL-u može se saznati da su neki sarkofazi s natpisima služili kao posuda, odnosno kamenica za ulje (sarcophagus pro vase oleario), kao npr. u Klisu ${ }^{47}$, u Kaštel Novome ${ }^{48}$ ili u Trogiru ${ }^{49}$, a ima i opisa kako su neki služili kao pojilišta za vodu (arca pro lacu), npr. u Kaštel Starome ${ }^{50}$ ili u Trogiru. ${ }^{51}$ Pri ovakvoj upotrebi spomenika nije bila potrebna nikakva preinaka. Kao dobar primjer iskorištavanja i preinake spomenika u uporabnu svrhu služi nadgrobna ara pronađena u samostanu Kćeri Božje ljubavi u Splitu koja je sa stražnje strane naknadno izdubljena kako bi služila ili kao kamenica ili kao pojilo. Nakon što je ispunio svoju drugu funkciju, spomenik je bio ugrađen u ogradni zid samostana (Demicheli 2016). Još jedna nadgrobna ara, ali na grčkome jeziku, dokumentirana je u Solinu u dvorištu privatne kuće gdje je tada imala funkciju kamenice za ulje (Abramić 1925: 7-8). U istu kategoriju ide i preinačeni natpis iz Kupinovika kod Dola na Hvaru koji je već u antičko doba poslužio kao stup tijeska za ulje ili vino (stipes). Izvorno je ovaj spomenik najvjerojatnije bio arhitrav građevine spomenute na samome natpisu (Zaninović 1996).$^{52}$ Kao posljednji primjer u ovome nizu spolija spomenut ću da se za potrebe sumpornih kupališta otvorenih u Splitu 1821. god. umjesto kada za kupelj koristilo šest antičkih sarkofaga (Duplančić 2014: 334).

\section{Zaključak}

Fenomen spolija vrlo je slojevit, o njemu se može mnogo šire raspravljati nego je to bilo obuhvaćeno ovom temom. U ovom općem pregledu epigrafskih spomenika u trenutku i mjestu njihova pronalaska može se podvući nekoliko činjenica. Bez obzira na razlog zašto kameni spomenici postaju spoliji, sigurno je da su oni sami posljedica složenih društvenih zbivanja na nekom području koja obuhvaćaju ekonomske prilike, vjeru, društveni status, obrazovanje, ali i

\footnotetext{
${ }^{47}$ CIL III 2046.

48 Salona IV, br. 194.

49 CIL III 14316.

50 CIL III 2446.

${ }^{51}$ CIL III 2704.

52 AE 1978, 615.
} 
kolektivnu svijest. Većina je natpisnih spolija izvađena iz njihova sekundarnog okruženja pa se danas ne može dobiti vizualni dojam o njihovoj uporabi tijekom povijesti na opisanom području. No ono što treba konstatirati jest činjenica da je upravo radi ponovne uporabe većina natpisa doživjela današnje doba. S jedne strane tu je prvotni negativan odnos prema antičkoj baštini, možda čak i barbarski čin otimanja kamenog ukrasa, skulpture i natpisa iz njihova prvobitnog ambijenta i ugradnja tih istih komada u nove građevine. $S$ druge strane to isto kamenje unutar zidova postalo je trajnije od mnogih komada koji nisu bili naknadno ugrađeni. Razvojem arheološke znanosti, ali i same epigrafije, počelo je masovno prikupljanje natpisa u muzeje. Česte su muzejske akvizicije bile natpisi otkriveni i izvađeni iz građevina te izloženi u sasvim novom prostoru. Ovakvim činom natpisi su dobili i novu svrhu, odnosno nastavio se njihov život koji i dalje traje te ih sasvim sigurno i dalje možemo smatrati spolijima jer se nalaze na mjestu koje im izvorno nije bilo predviđeno.

Na primjeru grada Salone može se doznati mnogo o odnosu prema spomenicima s nekropola jer je imala zanimljivu urbanističku situaciju. Dijelovi gradskih nekropola koji su se našli obujmljeni bedemima 170. god. uskoro više nisu bili u funkciji te su se u nekom razdoblju, vjerojatno i prije kasne antike, nadgrobni natpisi i dijelovi grobnih instalacija počeli koristiti kao građevinski materijal. Teško je ustanoviti kada su se natpisi počeli koristiti kao spoliji, ali je moguće da je salonitansko pučanstvo nešto spremnije pristajalo na ovakve građevinske intervencije nego na nekim drugim područjima.

Salona koja se istražuje zapravo je kasnoantički grad, dok je od njezina izgleda iz 1. ili iz 2. st. vrlo malo ostalo. Građevine podignute prije kasne antike vjerojatno su i dalje postojale, no tijekom vremena bile su obnavljane i dobivale su nove pečate vremena. Jedan od tih pečata su spoliji. Oni ne govore samo o jednoj određenoj praksi graditelja koja je mogla biti potaknuta mnogim razlozima, već i o još jednoj vrlo bitnoj stvari: govore o tome što je sve bilo izgrađeno. U teoriji znamo da su na području Salone morali postojati hramovi i mnoge druge javne vrste građevina koje su se morale nalaziti u koloniji i metropoli provincije, no u praksi one nisu uvijek potvrđene. Međutim, pronalasci kamenih spolija u vidu stupova, kapitela, arhitrava, ulomaka mramorne oplate i ostalih dijelova arhitektonske i dekorativne plastike navode na razmišljanje o građevinama kojim su mogli pripadati. Npr. hram vjerojatno posvećen Jupiteru u istočnome dijelu grada više ne postoji, niti je njegov točan položaj i izgled arheološki dokumentiran, no njegovi razgrađeni dijelovi i žrtvenik posvećen Jupiteru koji su iskorišteni pri gradnji odvodnih kanala svjedoče o njegovu postojanju. Ponekad su natpisi jedini siguran dokaz o postojanju nekog tipa objekta jer ga izrijekom spominju, što uvelike olakšava rekonstrukciju i života u antici. U širokom spektru arheoloških pronalazaka natpisi su tek jedna vrsta spolija koja možda nešto rječitije priča o svojoj funkciji, vremenu i ljudima od neke druge vrste obrađenog kamena u antici, no da bismo sagledali širu sliku, moramo uzeti u obzir i druge vrste kamenih spolija, kao i sav pokretni arheološki materijal kako bismo mogli predočiti skicu nekadašnjeg izgleda gradskog prostora u antici. 
AE - L'Année épigraphique, Paris

CIL - Corpus inscriptionum Latinarum, Berlin

ILJug - Inscriptiones Latinae quae in Iugoslavia repertae et editae sunt, Ljubljana

Salona IV - Inscriptions de Salone chrétienne IVe-VIIe siècles, Roma - Split 2010.

\section{Literatura}

Abramić, M. 1925. Grčki natpisi iz Solina. Vjesnik za arheologiju i historiju dalmatinsku 47-48. Split. 3-11.

Abramić, M. 1932. Spomenici iz bedema stare Salone. Vjesnik za arheologiju i historiju dalmatinsku 50. Split. 56-63.

Abramić, M. 1950. Zapadna nekropola antikne Salone. Vjesnik za arheologiju i historiju dalmatinsku 52. Split. 1-18.

Alchermes, J. 1994. Spolia in Roman cities of the Late Empire: Legislative rationales and Architectural reuse. Dumbarton Oaks Papers 48. 167-178.

Altekamp, S., Marcks-Jacobs, C. \& Seiler, P. (ur.) 2013. Perspektiven der Spolienforschung 1. Spoliierung und Transposition (Topoi 15). Berlin-New York.

Babić, I. 2006. Spolije na tlu ranosrednjovjekovne Hrvatske, Starohrvatska prosvjeta 33. Split. 91-125.

Babić, I. 2007. Zapažanja o zvoniku splitske katedrale. Vjesnik za arheologiju i povijest dalmatinsku 100. Split. 145-170.

Babić, I. 2016. Trogir - grad i spomenici. Književni krug Split i Muzej Hrvatskih arheoloških spomenika. Split.

Barišić, M. \& Marinković, V. 2011. Fenomen antičkih spolija - problem zaštite i prezentacije. Kulturna baština 37. Split. 317-338.

Brenk, B. 1987. Spolia from Constantine to Charlemagne: Aestethics versus ideology. Dumbarton Oaks Papers 41. 103-109.

Brøndsted, H. (ur.) 1928. Recherches à Salone, Frais de la Fondation Rask-Ørsted. Copenhagen.

Brunšmid, J. 1998. Natpisi i novac grčkih gradova u Dalmaciji. Književni krug Split. Split.

Bulić, F. 1902. Ritrovamenti antichi nelle mura perimetrali dell'antica Salona. L'iscrizione della „praefectura Phariaca Salonitana“. Bulletino di archeologia e storia dalmata 25. Split. 3-26.

Bulić, F. 1903. Il monumento sepolcrale di Pomponia Vera. Bulletino di archeologia e storia dalmata 26. Split. 3-15.

Bulić, F. 1907. Sterro di una chiesa antica cristiana del VI sec. nella localita detta Crkvina a Klapavice nell Comune Censuario di Klis (Clissa). Bulletino di archeologia e storia dalmata 30. Split. 101-122.

Bulić, F. 1910. Iscrizioni inedite trovate nelle macerie lungo le mura perimetrali dell'antica Salona. Bulletino di archeologia e storia dalmata 33, Split. 82-88.

Bulić, F. 1912. Scavi nelle basiliche urbane di Salona durante gli anni 1907, 1908, 1909. Bulletino di archeologia e storia dalmata 35. Split. 3-32.

Bulić, F. 1913. Trovamenti antichi e medioevali a Gradina di Salona. Bulletino di archeologia e storia dalmata 36. Split. 3-19. 
Bulić, F. 1914a. Iscrizioni trovate lungo le mura perimetrali Nord dell'antica Salona. Bulletino di archeologia e storia dalmata 37. Split. 49-59.

Bulić, F. 1914b. Escavi ad est della Porta Caesarea a Salona nei cosidetti Cinque Ponti (Pet Mostova). Bulletino di archeologia e storia dalmata 37. Split. 68-79.

Bulić, F. 1986. Po ruševinama stare Salone. Arheološki muzej u Splitu. Split.

Calvelli, L. 2015. A new legionary inscription from Venice. Sylloge epigraphica Barcinoensis 13. Barcelona. 87-100.

Calvelli, L., Crema, F. \& Luciani, F. 2017. The Nani museum. Greek and Latin inscriptions from Greece and Dalmatia. U: Illyrica antiqua II - in honorem Duje Rendić-Miočević (ur. D. Demicheli). Zagreb. FF Press. 265-290.

Cambi, N. 1984. Il reimpiego dei sarcofagi romani in Dalmazia. U: Colloquio sul reimpiego dei sarcofagi romani nel medioevo (ur. B. Andreae, S. Settis), Marburg. BPR Publishers.75-92.

Cambi, N. 1986. Salona i njene nekropole. Radovi Filozofskog fakulteta u Zadru 25 (12). Zadar. 61-107.

Cambi, N. 1987. Studije o antičkim spomenicima i zgradama u Splitu i okolici II. Reljef u južnom zidu crkve sv. Duha. Kulturna baština 17. Split. 7-18.

Cambi, N. 1994. Stele iz kasnoantičke grobnice u Dugopolju. Vjesnik za arheologiju i historiju Dalmatinsku 86. Split. 147-181.

Cambi, N. 1997. Studije o antičkim spomenicima i zgradama u Splitu i okolici IV. Reljef Ivana Evanđelista u crkvici sv. Jere na Marjanu. Kulturna baština 27-28. Split. 25-35.

Cambi, N. 2010. Sarkofazi lokalne proizvodnje u rimskoj Dalmaciji, Književni krug Split. Split.

Cambi, N. 2014. Lucije Artorije Kast: njegov grobišni areal i sarkofag u Podstrani (sveti Martin) kod Splita. U: Lucije Artorije Kast i legenda o kralju Arturu (ur. N. Cambi, J. Matthews), Književni krug Split. Split. 29-40.

Coates-Stephens, R. 2002. Epigraphy as spolia. The reuse of inscriptions in early medieval buildings. Papers of the British School at Rome, Cambridge 70. 275-296.

Cooley, A. (ur.) 2000. The afterlife of inscriptions: reusing, rediscovering, reinventing \& revitalizing ancient inscriptions. Institute of Classical Studies, School of Advanced Study, University of London. London.

Demicheli, D. 2008. Žrtvenik božice Salacije iz Trogira. Opuscula archaeologica 31. Zagreb. 6980.

Demicheli, D. 2009. Tri neobjavljena miljokaza iz Dalmacije. Obavijesti HAD-a 41/3. Zagreb. 60-69.

Demicheli, D. 2015a. U potrazi za natpisima Papalićeve zbirke: sarkofag Julija Kirana i Varije Flavije Salonije (ad CIL III 2584), Colloquia Maruliana 24. Split. 145-156.

Demicheli, D. 2015b. Conventus Liburnorum, conventus Scardonitanus, Vjesnik za arheologiju i historiju dalmatinsku 109. Split. 91-108.

Demicheli, D. 2016. Inscriptiones Spalatenses ineditae 2: nadgrobna ara Numerije Viktorine iz Veloga varoša. Vjesnik za arheologiju i historiju dalmatinsku 109. Split. 177-191.

Demicheli, D. 2017. Neobjavljeni i nepoznati rimskodobni natpisi iz istraživanja Ejnara Dyggvea u Šupljoj crkvi u Solinu. Tusculum 10. Solin. 175-197.

Demicheli, D. \& Demicheli, A. 2017. Počasna baza za kip cara Karakale iz Salone - njezina maštovita romanička prenamjena, današnje spajanje i novo čitanje. Tusculum 10. Solin. 39-55.

Demicheli, A. \& Demicheli, D. 2018. Salona AD 541: precisely dated sarcophagus of vaginarius (scabbard maker) Saturninus, fabrica armorum Salonitana and the plague of Justinian. Epigraphica 80. Faenza. (u postupku izdavanja). 
Duplančić, A. 1986. Nekoliko doživljaja don Frane Bulića iz njegove neobjavljene knjige o Saloni. Vjesnik za arheologiju i historiju dalmatinsku 79. Split. 315-348.

Duplančić, A. 2014. Reutilizacija antičkih sarkofaga i dvojica splitskih kanonika iz XV. I XVI. Stoljeća. Vjesnik za arheologiju i historiju dalmatinsku 107. Split. 331-365.

Duplančić, A. 2015. Četiri skulpture iz Salone i zapisi o njima. Tusculum 8. Solin. 175-194.

Egger, R. 1926. Forschungen in Salona II. Österreichischen Staatsdruckerei. Wien.

Elsner, J. 2001. From the culture of spolia to the cult of relics: The Arch of Constantine and the genesis of Late Antique forms. Papers of the British School at Rome 68. Cambridge. 149-184.

Fisković, I. 1981. Ranokršćanski sarkofazi otoka Brača, Vjesnik za arheologiju i historiju dalmatinsku 75. Split. 105-135.

Fortis, A. 2004. Put po Dalmaciji (preveo M. Maras). Marjan tisak. Split.

Gabričević, B. 1959. Una nuova iscrizione salonitana. U: Atti del III ${ }^{\circ}$ congresso internazionale di epigrafia greca e latina. „L〉Erma“ di Bretschneider. Roma. 77-80.

Glavinić, M. 1881. Iscrizioni inedite. Salona. Bulletino di archeologia e storia dalmata 4. Split. 17-19; 33-35; 49-51.

Jeličić-Radonić, J. 1998. Nova istraživanja gradskih zidina Salone. Prilozi povijesti umjetnosti u Dalmaciji 37. Split. 5-36.

Jeličić-Radonić, J. 2006a. Ara Tita Flavija Lucilija iz Salone. Vjesnik za arheologiju i povijest dalmatinsku 99. Split. 123-143.

Jeličić-Radonić, J. 2006b. Salona, the urbs orientalis. Hortus artium medievalium 12, Zagreb. 43-53.

Jeličić-Radonić, J. 2007. Salona at the time of bishop Hesychius. Hortus artium medievalium 13. Zagreb. 13-24.

Jeličić-Radonić, J. 2009. Diocletian and the Salona Urbs orientalis. U: Dioklecijan, tetrarhija $i$ Dioklecijanova palača, o 1700. obljetnici postojanja (ur. N. Cambi, J. Belamarić, \& T. Marasović). Split. Književni krug Split. 307-333.

Jeličić-Radonić, J. \& Pereža, D. 2011. Antičke spolije u solinskim Paraćima. Tusculum 4, Solin. 43-66.

Jurčević, A. 2007. Kasnoantičko i srednjovjekovno groblje na lokalitetu Crkvine u Klapavicama. Starohrvatska prosvjeta 34. Split. 249-265.

Kajanto, I. 1995. The survival of Latin inscriptions. U: Acta colloquii epigraphici Latini Helsingae 3-6. sept. 1991, (ur. H. Solin, O. Salomies \& U-M. Liertz). Societas Scientiarum Fennica. Helsinki. 13-18.

Kinney, D. 1995. Rape or restitution the past? Interpreting spolia. U: The art of interpreting (ur. S. C. Scott). Penn State Press. University Park. 53-67.

Kinney, D. 2006. The concept of spolia. U: A companion to medieval art: Romanesque and Gothic in Northern Europe (ur. C. Rudolph). Wiley-Blackwell. Hoboken NJ. 233-252.

Kovačić, V. 1994. Porta Dominica i crkva sv. Dujma u Trogiru. Prilozi povijesti umjetnosti u Dalmaciji 34. Split. 51-65.

Marasović, T., Marasović, J. \& Gabričević, B. 2014. Istraživanje i uređenje Peristila Dioklecijanove palače u Splitu 1956-1961. Split. Književni krug Split.

Mardešić, J. 2000. Istočni trakt gradskih zidina Salone. Opuscula archaeologica 23-24. Zagreb. 143-153.

Mardešić, J. \& Chevalier, P. 2004. Preliminarni izvještaj o hrvatsko-francuskim radovima u Saloni (2003). Episkopalni centar - Oratorij A. Vjesnik za arheologiju i historiju dalmatinsku 96. Split. 745-776. 
Marin, E., Mayer, M., Paci, G., Rodà, I. 1998. Corpus inscriptionum Naronitanarum 1, Erešova kula. Università degli studi di Macerata, Arheološki muzej Split; Editrice Tibergraf, Tivoli.

Maršić, D. 2010. Izgubljeni salonitanski spomenici (II). Portretne stele vojnika VII. legije C.p.f. Gaja Lukrecija i Lucija Cezija Basa. Vjesnik za arheologiju i povijest dalmatinsku 103. Split. 6380.

Miletić, Ž. 1989. Murazzo zapadne salonitanske nekropole. Radovi Filozofskog fakulteta u Zadru 28. Zadar. 49-70.

Miletić, Ž. 1990. Sjeverna salonitanska nekropola. Radovi Filozofskog fakulteta u Zadru 29. Zadar. 163-194

Miletić, Ž. 1992. Istočna i jugoistočna nekropola Salone. Radovi Filozofskog fakulteta u Zadru 30. Zadar. 21-50.

Matijević, I. 2006. Neobjavljeni natpisi iz Žrnovnice i Salone. Vjesnik za arheologiju i povijest dalmatinsku 99. Split. 145-152.

Matijević, I. 2014. Qui cucurrit frumentarius annos XI. Tusculum 7. Solin. 67-74.

Nodilo, H. 2008. Solin - novi most na Jadru. Hrvatski arheološki godišnjak 4. Zagreb. 490-492.

Piplović, S. 2005. Recikliranje arhitektonskih i skulpturalnih elemenata u Saloni. Radovi zavoda za povijesne znanosti HAZU u Zadru vol. 47. Zadar. 1-25.

Radić Rossi, I. 2008. Zaštitno arheološko istraživanje u vranjičkome podmorju 2005./2006. Tusculum 1. Solin. 17-34.

Rendić-Miočević, D. 1952. Tri povijesna natpisa iz Dalmacije. Vjesnik za arheologiju i historiju dalmatinsku 53. Split. 167-176.

Rendić-Miočević, D. 1985. M. Pompeius Silvanus. Statthalter der Provinz Dalmatien, in einer neugefunden saloitanischen Bauinschrift. Hermann Vetters Festschrift (ur. E. Plöckinger), Holzhausen. Wien. 151-154.

Sanader, M., Demicheli, D. 2017. The early Christian service of ostiarius on an unpublished sarcophagus with the inscriptions from Šuplja crkva site in Solin (Salona). U: Illyrica antiqua II - in honorem Duje Rendić-Miočević (ur. D. Demicheli). Zagreb. FF Press. 253-264.

Skelac, G. \& Vodička, K. 2009. Vranjic - obala. Hrvatski arheološki godišnjak 5. Zagreb. 658-660. Švonja, N. 2014. Antički spoliji u kući Benzon u Vranjicu. Vjesnik za arheologiju i historiju dalmatinsku 107. Split. 241-289.

Vodička Miholjek, K. 2008. Vranjic-južna obala. Hrvatski arheološki godišnjak 4, Zagreb. 541543.

Zaninović, M. 1996. Novi latinski natpis iz Dola na otoku Hvaru. U: Od Helena do Hrvata. Zagreb. Školska knjiga. 93-101. 